\title{
The Questionable Character of the Bar's Character and Fitness Inquiry
}

Leslie Levin

University of Connecticut School of Law

Peter Siegelman

University of Connecticut School of Law

Follow this and additional works at: https://opencommons.uconn.edu/law_papers

Part of the Legal Profession Commons

\section{Recommended Citation}

Levin, Leslie and Siegelman, Peter, "The Questionable Character of the Bar's Character and Fitness Inquiry" (2015). Faculty Articles and Papers. 419.

https://opencommons.uconn.edu/law_papers/419 


\title{
The Questionable Character of the Bar's Character and Fitness Inquiry
}

\author{
Leslie C. Levin, Christine Zozula, and Peter Siegelman
}

\begin{abstract}
Lawyers who engage in misconduct can do substantial harm. To screen out "unfit" lawyers, bar examining authorities collect detailed personal information from bar applicants. The rationale for this "character and fitness" inquiry is to identify who is likely to become a problematic lawyer. Despite the history of discrimination associated with this inquiry and the highly personal information requested, there has been no rigorous test of whether such predictions are possible. This article examines the information disclosed by 1,343 Connecticut bar applicants and their subsequent disciplinary records. It reveals that while some bar application data are associated with an elevated risk of future discipline, the predictive power of the data is extremely low. Moreover, several variables are more strongly associated with less severe discipline than with more severe discipline. We argue that some of the causal mechanisms linking application data to subsequent discipline may have more to do with career trajectory than with an underlying propensity to engage in misconduct.
\end{abstract}

\section{INTRODUCTION}

Lawyers occupy positions of power and trust in society. When they engage in misconduct, their actions not only hurt vulnerable clients and third parties, but also undermine public confidence in the legal profession and the administration of justice. In an effort to reduce the likelihood that such harm will occur, every state bar scrutinizes bar applicants' "moral character and fitness" to practice law (NCBE and ABA 2013, vii, 4-5). To demonstrate good character, bar applicants are required to provide detailed information about their backgrounds, including any prior unlawful conduct, academic misconduct, neglect of financial responsibilities, and psychological history. The assumption underlying the inquiry is that "from [such] evidence ... of past misconduct, bar examiners will be able to predict future behavior accurately enough to justify denying some applicants the chance to practice law" (Clarke 1995, 59).

Leslie C. Levin is a Professor of Law and the Associate Dean for Academic Affairs at the University of Connecticut School of Law. Direct all correspondence to (leslie.levin@law.uconn.edu), University of Connecticut School of Law, 65 Elizabeth Street, Hartford, CT 06105 ((860) 570-5207).

Christine Zozula (zozula@mail.uri.edu) is an Assistant Professor of Sociology at the University of Rhode Island.

Peter Siegelman (peter.siegelman@law.uconn.edu) is the Roger Sherman Professor of Law at the University of Connecticut School of Law.

This study was funded by a grant from the Law School Admissions Council (LSAC). The opinions and conclusions contained in this article are the authors' and do not necessarily reflect the position of LSAC. The authors gratefully acknowledge the assistance they received from the Connecticut Bar Examining Committee, the Office of the Chief Disciplinary Counsel, and the Statewide Grievance Commission. We also thank Emily Nix for expert assistance in finding and programming the appropriate test for pooling in multinomial logit regressions. 
The requirement that applicants seeking to become lawyers possess "good character" is rooted in the "professional project" (Larson 1977, 49; Gordon 2002), that is, the effort by lawyers to attain market monopoly, social status, and autonomy. The character requirement was historically used by the organized bar to exclude whole classes of individuals from the bar for reasons unrelated to their fitness to practice (Auerbach 1976; Abel 1989). Today, the stated purpose of the good character requirement is to protect both the public and the administration of justice by ensuring that only individuals who possess the requisite character and fitness are admitted to the bar (NCBE and ABA 2013, vii). Theorists also believe that the character inquiry serves to bolster the legal profession's reputation with the public and to maintain its status and prerogatives as a profession (Rhode 1985; Abel 1989; Cunningham 1992; Woolley 2007).

Surprisingly, however, it is unclear whether the data gathered during the character inquiry actually predict lawyer misconduct. The questions are not derived from-nor have they ever been validated using-psychological assessment tools and it is unclear what they actually measure. The process itself imposes nontrivial time and monetary costs on both applicants and bar authorities and impinges on applicants' privacy. The character and fitness requirement may also deter some people who would be good lawyers from pursing that career. Thus, it is important to understand which-if any-of the data being collected are actually useful in predicting future misconduct.

There have been no studies that validate the accuracy of predictions based on the information collected from bar applicants. This article reports on the first study that systematically examines whether the information revealed during the bar application process can be used to predict the likelihood that an applicant will be disciplined later in his or her legal career. In this study, we reviewed the admissions records of 1,343 lawyers admitted to the Connecticut bar from 1989-1992 and their subsequent disciplinary history (if any). The data reveal that many of the responses on the admissions application are statistically associated with discipline risk. ${ }^{1}$ Higher law school grades, attendance at a more prestigious law school, and being female significantly decrease the likelihood of discipline; having delinquent credit accounts, having been a party to civil litigation (excluding divorce), higher student loan debt, more traffic violations, and a history of a diagnosis of or treatment for psychological disorders increase it. These variables nevertheless make very poor predictors of subsequent discipline. The explanation for this seeming paradox is that the overall baseline likelihood of discipline is so low (only about 2.5 percent). Thus, even if some variable (e.g., having defaulted on a student loan) doubles the likelihood of subsequent disciplinary action-a very strong effect-the probability of subsequent discipline for an applicant with a student loan default is still only 5 percent.

The low predictive power of the character and fitness inquiry raises some important questions. To the extent that particular measures on the character and fitness inquiry are at all predictive of lawyer discipline, through what mechanism are those effects realized? Do the questions measure a propensity to offend, or do they predict lawyer discipline through other mediating factors, such as career trajectory? Do the low predictive value

1. We stress that our analysis throughout should be understood as predictive, rather than causal. Our data and methods do not allow us to say why some of our independent variables are associated with a higher risk of discipline. We do, however, offer some possible explanations for our findings in the Discussion section. 
and uncertain deterrent effects of the character and fitness questions outweigh their costs? And if not, should bar regulators consider alternative means either to reduce the likelihood of lawyer misconduct or to mitigate the harm caused by problem lawyers?

\section{THE CHARACTER AND FITNESS INQUIRY}

\section{Process}

The official character and fitness inquiry typically begins at the end of law school, when an applicant seeks admission to a state bar. ${ }^{2}$ It is usually conducted by a bar examining authority (or a "character and fitness" committee) that operates under the supervision of the state court. Applicants complete a lengthy form that reveals detailed information about past conduct, and they may also be required to produce substantiating documentation, including driving records, credit histories, and character references. Law schools also contribute information about their graduates' conduct and academic performance. The application file is then reviewed by the bar examining authority. A character and fitness hearing may be triggered by prior unlawful conduct, academic misconduct, neglect of financial responsibilities, substance dependency, and prior psychological problems, among other things (NCBE and ABA 2013, viii).

The moral character inquiry ostensibly seeks to determine "whether the present character and fitness of an applicant qualifies the applicant for admission" (NCBE and ABA 2013, viii-ix). In most states, past unlawful conduct merely creates a rebuttable presumption that an applicant lacks the requisite character to practice law (Swisher 2008). Bar examining authorities look at a variety of factors when considering past misconduct, including the seriousness and recency of the misconduct, the cumulative effect of the conduct, and evidence of rehabilitation (NCBE and ABA 2013, ix). The applicant's expressions of remorse and candor in the application process are considered important evidence of rehabilitation (Rhode 1985; Hoener 2008; Simon 2010).

\section{Critiques of the Character and Fitness Inquiry}

The character and fitness inquiry has been criticized on a variety of grounds, including its historic use to exclude minorities from the profession and its vague and inconsistent measurement of "good character." Indeed, "character" is an idea rooted in the virtue ethics of philosophy - and has been rejected by behavioral psychologists (Woolley and Stacey 2010, 170). Not surprisingly, the character and fitness inquiry has also been criticized for the substantial costs that are associated with a screening instrument that has not been rigorously assessed.

The character and fitness inquiry has been linked to the critical view of the professionalization of lawyers (Abel 1989). Starting in the late nineteenth century, the

2. In a few jurisdictions, the official character and fitness inquiry by bar examiners begins as early as the first year of law school. Law school applications also inquire about an applicant's character (Drienkowski 2004). In some cases, serious misconduct may lead to denial of law school admission. 
organized bar sought to create higher barriers to entry into the profession and pushed for increased educational, examination, and character requirements. According to critics, the push stemmed, in part, from concerns that "undesirable" elements were becoming lawyers and lowering the status of the legal profession (Auerbach 1976; Powell 1988). A more formal and rigorous character inquiry was instituted in the early twentieth century, in part, to restrict admission of immigrants who threatened the public standing and economic stability of the legal profession (Rhode 1985; Abel 1989; Swisher 2008). Black applicants were also disproportionately excluded on character and fitness grounds (Rhode 1985; Abel 1989). In addition, the character inquiry was sometimes used to deny admission to "radicals," including people who were thought to be communists (Schware v. Board of Bar Examiners 1957; Rhode 1985; Abel 1989). It was not until the 1980s that serious efforts began to define good character and to make the inquiry fairer to all applicants (Powell 1988; Corneille 2001).

The character and fitness inquiry has also been criticized in its recent iterations for leading to other, less overt, negative consequences. For example, the questions about a bar applicant's psychological history may deter law students from seeking psychological help (Coleman and Shellow 1994; Bauer 2001). Questions about credit history may disadvantage applicants from lower socioeconomic backgrounds. The focus on past criminal conduct may perpetuate racial and class biases, as people of color and the poor are subjected to differential treatment in the criminal justice system (Fortney 2004; Swisher 2008). Indeed, the very existence of the character and fitness inquiry may deter some people who might have made good lawyers from applying to law school.

The inquiry has also been criticized for the arbitrary and inconsistent nature of character determinations. Admissions authorities believe they are asking about indicia of poor character, but these questions have never been empirically validated as measures of this concept. Indeed, good character is not directly defined by the National Conference of Bar Examiners (NCBE), although it is manifested by a record of conduct "that justifies the trust" of clients, the courts and others (NCBE and ABA 2013, viii). A record revealing a notable deficiency in "honesty, trustworthiness, diligence, or reliability" may constitute a basis for denial of admission (NCBE and ABA 2013, viii). The US Supreme Court has stated that the inquiry should be whether "a reasonable man could fairly find that there are substantial doubts about [the applicant's] 'honesty, fairness and respect for the rights of others and for the laws of the state and nation"' (Konigsberg $v$. State Bar of California 1961). One problem, however, is that "reasonable men can readily disagree about what conduct would raise substantial doubts" (Rhode 1985, 530).

As a practical matter, very few applicants are actually denied admission to the bar on character and fitness grounds. Deborah Rhode's study (1985) found that only 0.2 percent of all applicants were denied admission on this basis. More recently, denial rates appear to range from 0.14 percent to 1 percent. $^{3}$ But the low denial rate may not mean that the character inquiry is without value. Perhaps the small number of applicants who are denied admission to the bar based on the character inquiry would have done some

3. R. David Stamm, former executive director of the Connecticut Bar Examining Committee, estimated that denial rates in Connecticut were consistently one or two people $(0.14$ percent) per year. Denial rates in some other states ranged from 0.18 percent to 1 percent (Missouri Board of Law Examiners 2011; Supreme Court of Ohio and the Ohio Justice System 2012). 
very bad things if allowed to practice law. The character inquiry may also deter an additional number of individuals who are chronic bad actors from ever seeking bar admission. ${ }^{4}$

The character inquiry is not, however, without significant costs. The character review process undertaken by bar examiners is labor intensive and expensive (requiring review of application materials for completeness and content, follow-up inquiries, interviews, etc.). The effort to amass the required information-often spanning a ten-year time period-is time consuming for applicants. Applicants who are required to participate in hearings find the process exceedingly stressful and (if they hire counsel) expensive. The process can cause embarrassment, interfere with work opportunities, and delay employment (Bauer 2001). Critics of the inquiry have argued that it would be better to devote resources to the investigation and discipline of wrongdoing by lawyers, rather than to force bar applicants to undergo a time-consuming and intrusive process (Rhode 1985). Alternatively, the regulation of law firm ethical infrastructures may prove to be more effective deterrents to wrongdoing (Parker, Gordon, and Mark 2010) than the character and fitness inquiry.

Even granting these critiques, a complete assessment of the character inquiry needs to take account of the potential benefits from screening. If the data can be used to predict future misconduct, the benefits may be significant. But if the data are not probative of misbehavior, the practice of collecting much of the information becomes more difficult to defend.

\section{Deviant Lawyers: Causes and Predictors}

As noted, the character inquiry has been criticized based on the absence of evidence that it succeeds in weeding out those individuals who are likely to do harm if they become lawyers. Commentators have also argued that the character and fitness inquiry cannot reasonably be expected to prevent admission of potentially "problem" lawyers because the inquiry comes too early to predict which applicants will subsequently misbehave (Rhode 1985). This argument has some force. Most discipline is imposed on middle-aged lawyers (Hatamyar and Simmons 2004; Abel 2008). These lawyers often report some depression related to work or life circumstances, alcohol abuse, or family or financial crises (Allan 1997; Langford 2005). These problems often arise several years after the character and fitness inquiry occurs (Benjamin et al. 1990). ${ }^{5}$

Moreover, lawyers learn important lessons about how to behave in practice after bar admission. The workplace is an important site where lawyers learn and construct

4. We do not know how many potentially bad lawyers do not pursue legal careers because they know they will be denied admission due to the character and fitness inquiry. Nor do we know how often bar authorities refuse to admit people who would have been satisfactory lawyers. This means that our assessment of the value of the inquiry is necessarily limited.

5. It is important to note, however, that even if the proximate causes of misbehavior are not known until after the bar application process, it may still be possible to predict subsequent discipline based on bar application data. For example, if low grades raise the odds of being a solo practitioner, this may predictably lead to overwork, lack of administrative resources and supervision, and depression, which can cause neglect of client matters, even though the depression did not exist at the time of admission. 
what it means to be a professional (Nelson and Trubek 1992; Suchman 1998). These lessons are learned from their communities of practice, that is, the "groups of lawyers with whom practitioners interact and to whom they compare themselves and look for common expectations and standards" (Mather, McEwen, and Maiman 2001, 6). Lawyer behavior in practice is also significantly affected by office size and practice specialty (Carlin 1966; Mather, McEwen, and Maiman 2001; Mather and Levin 2012). Clients' needs and financial means influence lawyer behavior, as do the office resources available to provide lawyers with support (Carlin 1966; Mather and McEwen 2012).

Although lawyer misconduct arises in many practice settings (Lerman 1999; Zacharias 2001), lawyer discipline is disproportionately imposed on solo or small-firm lawyers (Levin 2004; Abel 2008). The reasons for this are complex. These lawyers tend to work in "personal plight" areas such as criminal law, family law, and personal injury, where disputes are emotionally charged and clients are often vulnerable (Mather and McEwen 2012). The discipline process may be the only recourse available for these clients. In contrast, large-firm clients are repeat players who often have the leverage to force firms to remedy any wrongs without resorting to the discipline process (Wilkins 1992). Moreover, much of the discipline imposed is for neglect of client matters or failure to communicate with clients (Abel 2008; Mather and McEwen 2012). These problems are less likely to occur in larger firms due to their ethical infrastructures (Chambliss 2005) and are more likely to occur in solo and small firms due to insufficient office support. The disproportionate number of solo and small-firm lawyers who are disciplined may also reflect bias against them in the discipline system, as these lawyers occupy the lower rungs of the lawyer status hierarchy (Levin 2004; Heinz et al. 2005).

Only one previous study has sought to explore whether there is, in fact, a relationship between applicants who disclose "problem" behaviors during the bar admissions process and the subsequent imposition of discipline. Baer and Corneille (1992) reviewed fifty-two disciplined attorneys' bar admissions files and discipline records and compared them to the general population of all Minnesota bar applicants. They found that disciplined lawyers were more likely to reveal evidence of certain types of conduct in their admissions files (e.g., arrests, possible substance abuse, involuntary employment terminations, financial problems) than other bar applicants. They also found that lawyers who were disciplined were more likely than other lawyers to have failed the Minnesota bar examination at least once before they passed it, but as Corneille later noted, "the study was not conducted scientifically and involved a very small sample" (Corneille 2001, 16).

\section{THE STUDY DATA}

\section{General}

This study looks at the admissions records of Connecticut lawyers and their subsequent discipline history in an effort to determine whether information in the admissions files can predict which applicants will later be disciplined. The study population consisted of all lawyers admitted to the Connecticut bar from 1989 through 1992 $(N=6,159)$. These were the first four years in which the Connecticut Bar Examining 
TABLE 1.

Sample Totals by Disciplined and Never-Disciplined Lawyers

\begin{tabular}{lccc}
\hline & Total Sample & $\begin{array}{c}\text { Minus Those Missing } \\
\text { Application Data }\end{array}$ & $\begin{array}{c}\text { Equals: Included in } \\
\text { Regression Analysis }\end{array}$ \\
\hline Not disciplined & 1,259 & 61 & 1,198 \\
Disciplined & 152 & 7 & 145 \\
Total & 1,411 & 68 & 1,343 \\
\hline
\end{tabular}

Committee (CBEC) obtained credit reports and certified driving records for each applicant as part of the character inquiry, which provided a cross-check on some of the information supplied by the applicants. We identified all Connecticut lawyers in that population who had ever been publicly disciplined (e.g., disbarred, suspended, publicly reprimanded) in any US jurisdiction by searching the lawyer discipline records in Connecticut and all other jurisdictions. We also searched for Connecticut lawyers who had been privately disciplined in order to compile the list of disciplined lawyers $(\mathrm{N}=$ 152). ${ }^{6}$ We then randomly selected 1,259 lawyers ${ }^{7}$ admitted to the Connecticut bar from 1989-1992 who had never been disciplined. We subsequently excluded an additional sixty-eight lawyers whose admissions files could not be located by the CBEC after repeated efforts to do so. The final sample for the regression analysis totaled 1,343 lawyers (see Table 1 for sample totals).

Application data were coded directly from the CBEC's admissions files. Those files contained the completed Connecticut bar application, recommendation forms, employer affidavits, the dean's certificate, state motor vehicle reports, credit histories, and other correspondence. Discipline data were coded directly from the discipline files maintained by Connecticut's Office of Chief Disciplinary Counsel and the Statewide Grievance Commission. The discipline files typically contained the initial grievance, the finding of probable cause that misconduct had occurred, submissions made to the hearing panel, hearing transcripts, and the final decision imposing sanctions, although some of this information was missing from some files. In some cases, discipline information was also obtained from Connecticut court files and from records maintained by other states that imposed discipline on the Connecticut lawyers in the study.

Of course, this study can analyze only the information appearing in admissions files. While supporting documents from law schools, credit agencies, motor vehicle departments, and so forth are included in the application file to verify portions of the applicant's self-report, some applicants may have failed to disclose other important

6. Connecticut does not impose private discipline, but many other states do. Discussion of our efforts to identify Connecticut lawyers who were privately disciplined in other jurisdictions appears below.

7. We based our sample size of the lawyers who had never been disciplined on the frequency of lawyers who had been disciplined. A low frequency in the dependent variable would not render statistically meaningful results. Long (1997) states that having approximately 10 percent of the total sample in the dependent category is sufficient for statistical inquiry. 
information. ${ }^{8}$ For the purposes of this study, however, an applicant's failure to disclose does not matter, since we are only investigating whether the information that bar admissions authorities actually obtain predicts future discipline.

\section{Admissions Data}

Our independent variables come from the information included in the CBEC's admissions files (see Appendix Table A1 for the list of variables and see Table 2 for selected descriptive statistics). Some demographic information was not sought in the application, such as the applicant's race and gender. By recording male or female for obviously gendered names and checking voter registration and other records, we determined that the gender composition of the sample was 60 percent male and 40 percent female.

Application data did include the name of the law school from which the applicant graduated. To determine the "Rank of Law School Attended," we used data from the 1993 US News $\mathcal{E}$ World Report rankings as a rough measure (U.S. News \& World Report 1993). The 1993 report ranked law schools individually from 1-25, and then by quartiles for the remaining law schools. We coded law school rank as a dummy variable (= 1 for law schools in the bottom 50 percent of rankings, 0 otherwise). ${ }^{9}$

Lawyers in our sample took several different versions of the LSAT and it is possible that some did not take it at all. ${ }^{10}$ The Law School Admissions Council (LSAC) recommends that LSAT scores across different iterations of the test be compared using percentile score distributions, as "[s]cores cannot be converted from one scale to another in a fashion that would permit confidence that the converted score has the same meaning as scores originating on the scale to which the conversion is made" (Law Services 1991, 21). We used percentile data from LSAC to estimate a percentile score for each applicant who reported taking the LSAT.

\section{Discipline Data}

Our dependent variable in the analysis is whether or not a lawyer was disciplined between the time of bar admission in Connecticut and 2010. We recognize that

8. For example, psychological history is difficult to ascertain without self-disclosure. In addition, in Connecticut, criminal records were not routinely searched by the CBEC from 1989-1992, so criminal convictions that were not revealed by applicants may not have come to the attention of the CBEC. Each applicant did, however, sign a consent form authorizing the CBEC to obtain a variety of records concerning the applicant, including criminal records. Thus, it is likely that most applicants self-disclosed convictions on the theory that it was preferable to do so rather than to face additional difficulties in the application process due to lack of candor.

9. In analyses not shown, we also coded law schools by separating schools into the top $10,11-25$, the remainder of the first quartile, and the second, third, and fourth quartiles. For this article, we selected one variable for law school rank in order to present a more parsimonious model. For analyses with a more detailed breakdown of law school rank, see Levin, Zozula, and Siegelman (2013).

10. The LSAT was first administered in 1948-1949 and was not widely adopted until the 1960s. Some of the lawyers in the sample who were admitted to the Connecticut bar during 1989-1992 had attended law school and been admitted in other jurisdictions before the widespread use of the LSAT. For a fuller description of how the LSAT scores were coded, see Levin, Zozula, and Siegelman (2013). 
TABLE 2.

Frequencies of Selected Variables for Total Sample

\begin{tabular}{|c|c|c|c|c|}
\hline & \multicolumn{4}{|c|}{ Total Sample } \\
\hline & Percentage & Mean & $\mathbf{N}$ & Total N \\
\hline $\begin{array}{l}\text { Female } \\
\text { Application Data }\end{array}$ & 40.00 & & 540 & 1,350 \\
\hline $\begin{array}{l}\text { Prior Encounters with the Bar } \\
\text { Prior application } \\
\text { Prior discipline }\end{array}$ & $\begin{array}{l}7.53 \\
0.37\end{array}$ & & $\begin{array}{r}101 \\
5\end{array}$ & $\begin{array}{l}1,342 \\
1,342\end{array}$ \\
\hline $\begin{array}{l}\text { Academic History } \\
\text { Law school ranked in bottom 50\% } \\
\text { LSAT score (percentiles) }\end{array}$ & 39.15 & 65.87 & $\begin{array}{r}525 \\
1,209\end{array}$ & $\begin{array}{l}1,341 \\
1,209\end{array}$ \\
\hline $\begin{array}{l}\text { Credit History } \\
\text { Nonstudent loan debt } \\
\text { Student loan debt } \\
\text { Delinquent accounts } \\
\text { Bankruptcies }\end{array}$ & $\begin{array}{l}8.96 \\
0.30\end{array}$ & $\begin{array}{l}22.74 \\
13.16\end{array}$ & $\begin{array}{r}1,326 \\
1,328 \\
119 \\
4\end{array}$ & $\begin{array}{l}1,326 \\
1,328 \\
1,328 \\
1,338\end{array}$ \\
\hline $\begin{array}{l}\text { Civil, Criminal, } \mathbb{E} \text { Traffic Measures } \\
\text { Criminal conviction } \\
\text { Ever have traffic violation } \\
\text { Number of traffic violations } \\
\text { Driver's license suspensions } \\
\text { Litigation alleging fraud } \\
\text { Civil litigation }\end{array}$ & $\begin{array}{r}2.46 \\
53.45 \\
\\
6.21 \\
0.67 \\
14.58\end{array}$ & 1.01 & $\begin{array}{r}33 \\
712 \\
1,273 \\
83 \\
9 \\
195\end{array}$ & $\begin{array}{l}1,340 \\
1,332 \\
1,273 \\
1,337 \\
1,340 \\
1,337\end{array}$ \\
\hline $\begin{array}{l}\text { Health } \\
\text { Substance abuse } \\
\text { Mental or emotional disorder }\end{array}$ & $\begin{array}{l}0.97 \\
2.16\end{array}$ & & $\begin{array}{l}13 \\
29\end{array}$ & $\begin{array}{l}1,343 \\
1,343\end{array}$ \\
\hline
\end{tabular}

Total $N=1,350$; application data $N=1,343$.

discipline is an imperfect proxy for misconduct for a variety of reasons. First, much lawyer misconduct is never detected, reported, or sanctioned through formal channels (Wilkins 1992; Levin 2004). The imposition of disciplinary sanctions also potentially confounds the behavior of at least three separate actors: a lawyer (whose behavior generates a complaint); a complainant (who decides whether to file a grievance); and the bar's disciplinary authorities (who decide whether to impose sanctions). Nevertheless, other methods of measuring lawyer misconduct-for instance, looking at grievances filed or probable cause determinations-are even more problematic. Both are virtually impossible to obtain from out-of-state authorities. Moreover, grievances often do not reflect any misconduct by a lawyer-it is not uncommon to find grievances filed against lawyers by disgruntled clients who are unhappy with the bill or the result. Probable cause determinations by the disciplinary authorities are also poor measures of lawyer misconduct because the standard for finding probable cause is low and the findings are often made simply because a lawyer fails to respond to a grievance.

Another problem with the use of disciplinary sanctions as the dependent variable arises from jurisdictional variations in sanctioning. Every state and the District of 
Columbia has a lawyer discipline system that can impose sanctions on those admitted to their bar and 75 percent of the lawyers in the sample were admitted to the bar of at least one jurisdiction in addition to Connecticut. All jurisdictions impose public discipline in the form of disbarments and suspensions, and some form of public reprimand for less serious misconduct; many also impose conditions such as probation or continuing legal education (e.g., an ethics or law office management course). Private discipline can be imposed for "minor" misconduct in most jurisdictions, although Connecticut and a handful of other jurisdictions do not impose private sanctions. ${ }^{11}$ Thus, disciplinary sanctions do not have equivalent meanings in each jurisdiction and they are imposed by decision makers working within different systems who apply somewhat different standards.

Moreover, information about private discipline is often impossible to obtain. ${ }^{12} \mathrm{We}$ searched publicly available lawyer discipline databases and contacted out-of-state disciplinary authorities in order to identify each lawyer admitted in Connecticut from 1989-1992 who was disciplined in any US jurisdiction. In some cases, authorities informed us if any of the lawyers in our sample who were also admitted in their jurisdictions had been privately disciplined there. Occasionally, we also found descriptions of private discipline imposed on a lawyer in public documents. In many cases, however, we were unable to determine whether a lawyer in our sample who was admitted in another jurisdiction had been privately disciplined by that jurisdiction. ${ }^{13}$

Ultimately, we believe that in spite of these limitations, bar discipline identifies much of the most serious misconduct, including lawyers who steal from clients and those who are convicted of serious crimes. The imposition of discipline is thus at least a crude measure of whether a lawyer has departed from the standards of professional conduct expected of members of the bar and it is the only measure that is readily available.

\section{ANALYSIS}

\section{Description of Disciplined Lawyers}

Lawyers may be professionally disciplined for misconduct in connection with their duties as lawyers. They may also be disciplined for criminal or other behavior that may or may not be directly related to their work, but is deemed unacceptable for someone in a position of civic trust. The disciplined lawyers in the sample primarily were disciplined for professional rule violations involving the failure to communicate with clients

11. As of 2009, eleven other jurisdictions did not impose private discipline sanctions, including the District of Columbia, Florida, Illinois, Maryland, and New Jersey (ABA 2010, Chart II). Nevertheless, most of them imposed private discipline for at least some period from 1989-2009.

12. In addition, some states also have diversion programs, which permit lawyers who commit minor misconduct to avoid disciplinary sanctions by complying with certain requirements, such as attending a law office management course. This information is also private and only a few jurisdictions would confirm that the Connecticut lawyers also admitted to the bar in their states had not been subject to diversion.

13. While missing data are always a legitimate concern, our best estimate is that if all private discipline were known, the true discipline rate in our sample would be 10.4 percent instead of 10.3 percent. See Levin, Zozula, and Siegelman (2013, Appendix B) for a detailed analysis. 
TABLE 3.

Disciplined Lawyers, by Severity

\begin{tabular}{lrr}
\hline & Number & \% of Total \\
\hline Less severely disciplined & 94 & 61.84 \\
Severely disciplined & 58 & 38.16 \\
Total & 152 & 100.00 \\
& & \\
\hline
\end{tabular}

(20 percent), lack of diligence ( 17.9 percent), and the failure to properly safeguard client property ( 11.3 percent)..$^{14}$ In addition, twenty-eight lawyers received sanctions because they were convicted of crimes, ranging from conspiracy to commit murder to lesser crimes such as driving under the influence, though some of these lawyers also received sanctions for independent incidents of misconduct.

After looking at disciplined lawyers as a single group, we also broke the disciplined lawyers into two categories: severely disciplined and less severely disciplined. "Severely disciplined" lawyers were those who, after admission to the Connecticut bar, were suspended for two or more years, disbarred, or resigned and waived the right to reapply in response to charges of serious misconduct. This group also includes (1) lawyers whose misconduct resulted in interim suspensions of indeterminate length due to serious misconduct that probably would have resulted in severe discipline and (2) lawyers who were placed on inactive/disability status after engaging in serious misconduct that otherwise probably would have resulted in severe discipline. "Less severely disciplined" lawyers received lower-level sanctions, including shorter suspensions, reprimands, and conditions such as probation. Table 3 breaks down the disciplined lawyers by severity of discipline imposed. As explained below, the two types of sanctions appear to track distinct types of misbehavior and are in turn predicted by different variables.

For those who were disciplined, the average length of time between admission and the filing of a grievance leading to a sanction was 10.7 years. At the time the grievance complaint was filed, most of the lawyers were working in solo or small (two- or three-lawyer) law firms. In fact, only eight of the disciplined lawyers practiced in firms with more than ten lawyers and only two of those lawyers practiced in large firms (over fifty lawyers). ${ }^{15}$ Most of the lawyers (72.4 percent) were disciplined only once and the majority of those lawyers (56.9 percent) received no greater sanction than a public reprimand.

\section{Differences Between the Disciplined and Never-Disciplined Lawyers}

Figure 1 presents a broad overview of the differences between the disciplined and never-disciplined lawyer samples for selected variables. Three conclusions are apparent.

14. For a more detailed discussion of the rule violations, see Levin, Zozula, and Siegelman (2013).

15. It was not always possible to determine whether lawyers were working in solo firms or whether they had one or two other lawyers working with them. To make that determination, we relied on transcripts and other materials in the disciplinary files. 


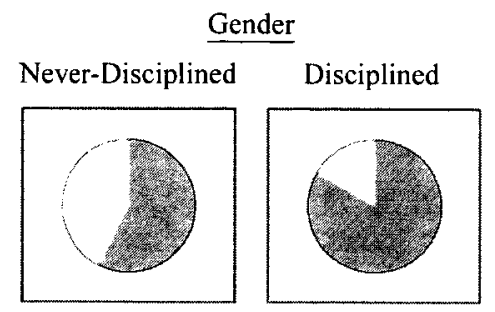

Male

C. Female

Driver's License Suspension

Never-Disciplined Disciplined
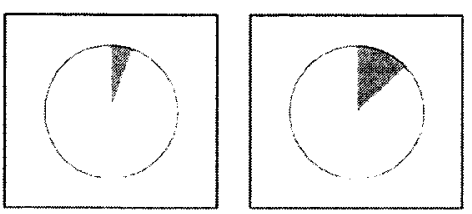

圆 Driver's License Suspension

No Driver's License Suspension

Criminal Conviction

Never-Disciplined Disciplined

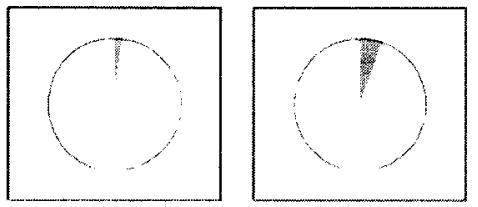

國 Criminal Conviction

[. No Criminal Conviction

Mental or Emotional Disorders Never-Disciplined Disciplined
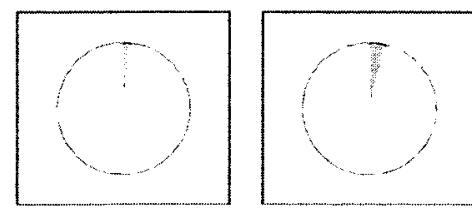

圆 Mental or Emotional Disorder

r.. No Mental or Emotional Disorder
Rank of Law School

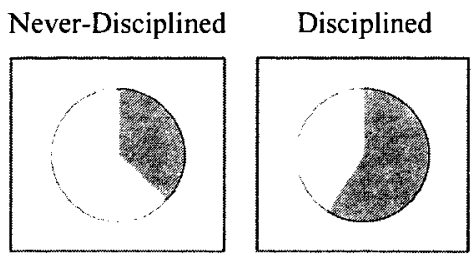

圈 Bottom 50\%

Top $50 \%$

Traffic Violations

Never-Disciplined Disciplined
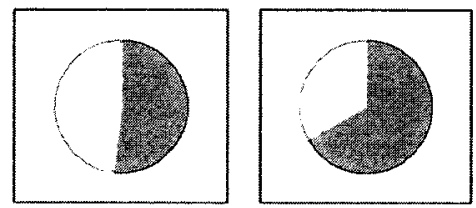

圈 Traffic Violations

II.) No Traffic Violations

Delinquent Accounts

Never-Disciplined Disciplined

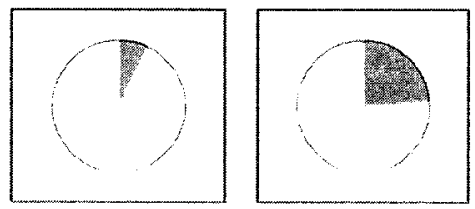

圆 Delinquent Accounts

[: No Delinquent Accounts

Substance Abuse

Never-Disciplined Disciplined

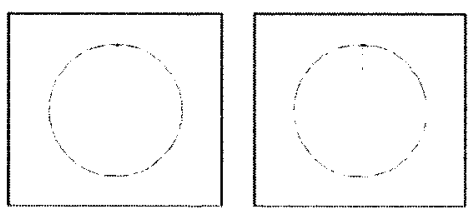

Substance Abuse

No Substance Abuse

FIGURE 1.

Differences Between Never-Disciplined and Disciplined Lawyers

First, at the time of application, there are some sharp contrasts between the group of lawyers who were subsequently subject to discipline and those who were not, along many dimensions.

Second, these differences are largely in line with intuitions about factors that would predict future discipline. For example, as Figure 1 indicates, while 16.6 percent of 
the disciplined lawyers were female, 42.7 percent of those in the never-disciplined sample were women. The overrepresentation of men among the disciplined lawyers is consistent with studies of lawyers in other jurisdictions (Curtis and Kaufman 20032004; Hatamyar and Simmons 2004; Bartlett 2008) and with the sociology of deviance more generally. Similarly, lawyers who were subsequently disciplined were more than twice as likely to report having had a preapplication psychological diagnosis/treatment as those who were not ( 4.1 percent vs. 1.9 percent). Fifty-nine percent of the disciplined group attended a law school ranked in the bottom half, compared to 36.8 percent of the lawyers who were not disciplined. Disciplined lawyers were also more than twice as likely to report having had a preapplication criminal conviction (5.6 percent vs. 2.1 percent), having had their driver's license suspended ( 13.1 percent vs. 5.4 percent), and having had delinquent credit accounts ( 23.8 percent vs. 7.2 percent). Thus, at the time of application to the bar, subsequently disciplined lawyers were manifestly "worse" on a variety of measures of socially disfavored variables.

Third, Figure 1 reveals that while some of the predictor variables differ strongly across the two groups, their absolute levels are mostly quite low. For example, even though disciplined lawyers are more than twice as likely to have had their driver's license suspended as never-disciplined lawyers, the overall prevalence of license suspensions ( 6.21 percent) is still very small in absolute terms. The implication is that the data do not provide a very powerful basis for predicting the likelihood of future discipline, a theme to which we return in the Discussion section below.

Of course, not every variable is more strongly associated with the disciplined group. For instance, none of the disciplined lawyers reported bankruptcy on their applications, as compared to four of the never-disciplined lawyers (results not shown). Also, the rate of substance dependency/treatment does not significantly vary between the disciplined and never-disciplined groups.

In sum, the comparisons in Figure 1 demonstrate that there are some differences between the never-disciplined and disciplined groups across specific variables. The comparisons do not tell us, however, how significant these differences are for predicting the likelihood of discipline and they only consider each variable individually, without controlling for the effects of other variables. For that, we turn to regression analysis.

\section{Logistic Regression Analysis}

We use logistic regression analysis to assess the effects of the independent or explanatory variables (measured at the time a lawyer is admitted to the bar) on the probability that he or she will subsequently be disciplined, controlling for all other independent variables included in the regression. Table 4 presents our basic models predicting the probability of discipline. The coefficients in these logistic regressions are marginal effects that capture the change in the probability of discipline from a one-unit change in the independent variable of interest. ${ }^{16}$ The regressions are weighted to reflect

16. Since the regression is nonlinear, the coefficients are not constant: Coefficients on continuous variables are evaluated at their sample average value, while coefficients for dummy variables measure the effect of moving from $X=0$ to $X=1$. By way of comparison, an ordinary least squares regression (linear probability model) produced largely similar results, with an $R^{2}$ coefficient of only 0.037 . 
64 LAW \& SOCIAL INQUIRY

TABLE 4.

Logistic Regression Predicting Both Types of Discipline; Marginal Effects Specification

\begin{tabular}{|c|c|c|c|}
\hline & Model 1 & Model 2 & Model 3 \\
\hline \multicolumn{4}{|l|}{ Character Variables } \\
\hline Prior discipline & $\begin{array}{c}-2.8800 \\
(6.9680)\end{array}$ & & $\begin{array}{c}0.4930 \\
(7.2540)\end{array}$ \\
\hline Discipline, academic deficiency & $\begin{array}{c}.0001 \\
(0.0084)\end{array}$ & & $\begin{array}{c}-0.0104 \\
(0.0090)\end{array}$ \\
\hline Discipline, other & $\begin{array}{c}-0.0029 \\
(0.0206)\end{array}$ & & $\begin{array}{c}0.0026 \\
(0.0203)\end{array}$ \\
\hline Negative feedback, dean's certificate & $\begin{array}{c}-0.0241 \\
(0.0237)\end{array}$ & & $\begin{array}{c}-0.0322 \\
(0.0240)\end{array}$ \\
\hline Negative feedback, letters & $\begin{array}{c}-0.0012 \\
(0.0111)\end{array}$ & & $\begin{array}{c}-0.0048 \\
(0.0107)\end{array}$ \\
\hline Work discipline & $\begin{array}{c}0.0046 \\
(0.0066)\end{array}$ & & $\begin{array}{c}0.0058 \\
(0.0067)\end{array}$ \\
\hline Default on student loan & $\begin{array}{c}0.0057 \\
(0.0107)\end{array}$ & & $\begin{array}{c}0.0077 \\
(0.0120)\end{array}$ \\
\hline Judgment against by creditor & $\begin{array}{c}0.0035 \\
(0.0141)\end{array}$ & & $\begin{array}{c}-0.0032 \\
(0.0143)\end{array}$ \\
\hline Delinquent accounts & $\begin{array}{l}0.0273^{* * *} \\
(0.0064)\end{array}$ & & $\begin{array}{l}0.0251^{* * *} \\
(0.0069)\end{array}$ \\
\hline Bankruprcies & $\begin{array}{c}2.9270 \\
(6.9680)\end{array}$ & & $\begin{array}{c}-0.455 \\
(7.2540)\end{array}$ \\
\hline Nonstudent loan debt & $\begin{array}{r}.0000^{*} \\
(.0000)\end{array}$ & & $\begin{array}{c}.0000 \\
(.0000)\end{array}$ \\
\hline Student loan debt & $\begin{array}{l}0.0004^{* * *} \\
(0.0001)\end{array}$ & & $\begin{array}{l}0.0004 * * * \\
(0.0001)\end{array}$ \\
\hline Criminal convictions & $\begin{array}{c}0.0109 \\
(0.0142)\end{array}$ & & $\begin{array}{c}0.0125 \\
(0.0130)\end{array}$ \\
\hline Traffic violations, number & $\begin{array}{l}0.0040^{* * *} \\
(0.0015)\end{array}$ & & $\begin{array}{c}0.0028^{*} \\
(0.0015)\end{array}$ \\
\hline Driver's license suspensions & $\begin{array}{c}0.00624 \\
(0.0080)\end{array}$ & & $\begin{array}{c}0.0013 \\
(0.0087)\end{array}$ \\
\hline Civil litigation & $\begin{array}{l}0.0135^{* *} \\
(0.0056)\end{array}$ & & $\begin{array}{l}0.0146^{* *} \\
(0.0057)\end{array}$ \\
\hline Litigation alleging fraud & $\begin{array}{c}-0.0113 \\
(0.0340)\end{array}$ & & $\begin{array}{r}-0.00873 \\
(0.0367)\end{array}$ \\
\hline Substance abuse & $\begin{array}{c}-0.0053 \\
(0.0256)\end{array}$ & & $\begin{array}{l}-0.0081 \\
(0.0225)\end{array}$ \\
\hline Mental or emotional disorder & $\begin{array}{r}0.0222^{*} \\
(0.0122)\end{array}$ & & $\begin{array}{c}0.0334^{* *} \\
(0.0134)\end{array}$ \\
\hline Demographic Variables & & & \\
\hline Age & & $\begin{array}{c}0.0003 \\
(0.0003)\end{array}$ & $\begin{array}{c}0.0001 \\
(0.0004)\end{array}$ \\
\hline Female & & $\begin{array}{l}-0.0246^{* * *} \\
(0.0041)\end{array}$ & $\begin{array}{l}-0.0249 * * * \\
(0.0042)\end{array}$ \\
\hline 1989 & & $\begin{array}{c}-0.0049 \\
(0.0058)\end{array}$ & $\begin{array}{c}-0.0029 \\
(0.0064)\end{array}$ \\
\hline 1990 & & $\begin{array}{c}-0.0027 \\
(0.0059)\end{array}$ & $\begin{array}{c}-0.0019 \\
(0.0064)\end{array}$ \\
\hline
\end{tabular}


TABLE 4.

(Continued)

\begin{tabular}{|c|c|c|c|}
\hline & Model 1 & Model 2 & Model 3 \\
\hline 1991 & & $\begin{array}{c}-0.0017 \\
(0.0060)\end{array}$ & $\begin{array}{c}-0.0023 \\
(0.0063)\end{array}$ \\
\hline Prior application & & $\begin{array}{c}0.0089 \\
(0.0078)\end{array}$ & $\begin{array}{c}0.0124 \\
(0.0079)\end{array}$ \\
\hline Waived in & & $\begin{array}{c}-0.0053 \\
(0.0095)\end{array}$ & $\begin{array}{l}-0.0060 \\
(0.0106)\end{array}$ \\
\hline Armed services & & $\begin{array}{c}0.0016 \\
(0.0089)\end{array}$ & $\begin{array}{c}0.0019 \\
(0.0094)\end{array}$ \\
\hline Law school ranked bottom $50 \%$ & & $\begin{array}{l}0.0177^{* * *} \\
(0.0059)\end{array}$ & $\begin{array}{l}0.0170^{* * *} \\
(0.0059)\end{array}$ \\
\hline Class rank & & $\begin{array}{c}-0.0103 \\
(0.0130)\end{array}$ & $\begin{array}{l}-0.0094 \\
(0.0139)\end{array}$ \\
\hline Average grade & & $\begin{array}{l}-0.0064^{* * * *} \\
(0.0020)\end{array}$ & $\begin{array}{l}-0.0049^{* *} \\
(0.0020)\end{array}$ \\
\hline LSAT (percentile) & & $\begin{array}{c}0.0074 \\
(0.0150)\end{array}$ & $\begin{array}{c}0.0061 \\
(0.0155)\end{array}$ \\
\hline$N$ & 1,343 & 1,343 & 1,343 \\
\hline
\end{tabular}

${ }^{* * *} p<0.01 ;{ }^{* *} p<0.05 ;{ }^{*} p<0.1$. Standard errors in parentheses. Missing mean substitution. All variables held at mean. Coefficients are marginal effects that measure the change in likelihood of discipline given a one unit change in the independent variable.

the fact that we have application data for all but seven of the disciplined lawyers admitted from 1989 to 1992 and a random sample of roughly 20 percent of the never-disciplined lawyers. A useful starting point is the observation that the baseline probability of discipline (with no controls) is roughly $150 / 6,200$, or 2.4 percent. Missing data in these logistic regression analyses are treated with mean substitution. Only 2.97 percent of the observations were missing. ${ }^{17}$

Model 1 of Table 4 includes only variables that seem directly related to an assessment of "character," narrowly defined. These include the presence of disciplinary action in college or law school, negative feedback on the dean's certificate and references, termination from employment, a poor credit history, traffic offenses, involvement in criminal and civil litigation, and reported mental health and substance abuse problems. We deliberately exclude "background" or "demographic" variables such as gender and rank of law school attended that - while they may be predictive of discipline risk-are not themselves relevant to an assessment of "character."18 By way of overview, Model 1

17. We chose mean substitution so that we did not need to drop any observations and because we were missing less than 3 percent of our observations. We also ran regression analyses dropping missing cases and using mean substitution for disciplined lawyers and never-disciplined lawyers. See Levin, Zozula, and Siegelman (2013, Appendix Tables 4-5.2).

18. The distinction between "character" and "demographic" variables admittedly is not clear cut, but we adopt an expansive definition of which variables measure "character" so as to give character variables the greatest possible chance to explain subsequent discipline. 
is not particularly useful at predicting future discipline risk; the variables that best track "character" are mostly not statistically significant and those that are have fairly low effect sizes.

Some credit history variables are associated with an increased likelihood of discipline. For example, each additional thousand dollars of student debt raises the probability of discipline by 0.04 percentage points and this result is highly significant $(p<$ $.01)$. In the case of nonstudent debt, however, the effect size is negligible. ${ }^{19}$ Having delinquent credit accounts increases the likelihood of discipline by about 2.73 percentage points, and the effect is statistically significant $(p<.01)$.

Prior involvement with the criminal or civil justice system raises the chances that an applicant will be disciplined after admission, but for most variables, the effects are small and are not well-measured. Having a prior criminal conviction is associated with a roughly 1.09 percentage points greater chance of discipline, though the effect is not statistically significant. Having been a party to a civil suit (as either plaintiff or defendant), raises the discipline probability by 1.35 percentage points, and this effect is moderately significant $(p<.05) .^{20}$ Traffic violations are associated with a higher discipline risk, with each additional violation adding about 0.4 percentage points to the likelihood of discipline. This effect is statistically significant $(p<.01)$.

Finally, substance dependency or treatment does not raise the probability of discipline, but reported diagnosis of or treatment for psychological disorders is associated with higher discipline risk. The effect is large-about 2.2 percentage points-and weakly significant $(p<.10)$. But it remains true that someone with a record of mental health diagnosis/treatment is still overwhelmingly unlikely to be disciplined: The baseline probability of discipline for someone with no reported mental health diagnosis/ treatment is only about 2.5 percent, so having such history only raises the probability of discipline to about 5 percent, holding all other variables constant.

In sum, Model 1 of Table 4 shows that while some character variables are predictive of future lawyer discipline, most have very low effect sizes. In Model 2, we look at the predictive effect of "background variables" including, age, year of application, military service, and academic history on the likelihood of discipline.

Consistent with the social deviance and criminology literature (Covington and Bloom 2003; Simon and Ahn-Redding 2005), gender has a statistically significant effect on the probability of being disciplined: being male raises the probability of discipline by approximately 2.5 percentage points. Put another way, women have a 1 percent chance of being disciplined, while men have about a 3.5 percent chance, all else equal. The effect is statistically significant $(p<.01)$. On the other hand, at 3.5 percent, the probability of discipline is still very low in absolute terms. Other background variables - in particular, the year of application/cohort variables-are mostly very small in magnitude and insignificant. Thus, there are no obvious time-related trends in the

19. Nonstudent debt is presumably largely mortgage debt. Without knowing more, it is difficult to say whether a larger mortgage is indicative of financial stress or simply a higher level of income.

20. Civil litigation in these models excludes divorce proceedings. We also ran a model that controlled for whether or not a lawyer had been divorced at the time of application (table not shown). The effect of divorce was not statistically significant and did not notably alter the effect of any other variables in the regression model. 
likelihood of discipline and no cohort of applicants significantly or substantively differs in the likelihood of discipline from the others.

We also included academic performance measures in Model 2 of Table 4, as we believe performance on the LSAT, prestige of law school, and performance while in law school are predictive of career trajectory. Generally speaking, lawyers who perform less well on these measures are more likely to work in solo or small firms (Heinz et al. 2005), where discipline is more likely to be imposed. Among the academic history variables, attendance at a more prestigious law school is associated with a reduction in the probability of discipline. Those who graduate from the bottom half of law schools have a 1.7 percentage points higher chance of discipline than those who graduate from the top 50 percent of law schools. Higher law school grades and class rank in law school are both negatively associated with discipline risk, but the effect is only statistically signifcant for grades $(p<.01) .{ }^{21}$ Controlling for class rank and law school grades, LSAT score has essentially no effect on the likelihood of discipline.

We now turn to a model that includes all variables--both those that are related directly to character and fitness and those that are largely sociodemographic. Model 3 of Table 4 allows us to see the effect of "character" variables after controlling for the effects of demographic and academic performance variables. We find that the "character" variables that predicted the likelihood of discipline in Model 1 continue to do so, with fairly consistent effect sizes and statistical significance. Combining "character" and "demographic" variables in Model 3, we find that being a woman and having higher law school grades reduce the likelihood of discipline, which is consistent with Model 2. Having attended a less prestigious law school, having delinquent credit accounts, and having higher student loan debt are associated with an increased risk of discipline. Likewise, having a number of traffic violations, having been a party to civil litigation (excluding divorce), and having been diagnosed with or treated for a psychological disorder are also associated with an increased risk of discipline.

The only notable changes in effects in Model 3 of Table 4 are bankruptcy and diagnosis/treatment for a psychological disorder. Having had a previous bankruptcy now dramatically lowers the risk of future discipline, which is to be expected given that all those in the sample who experienced a bankruptcy were in the never-disciplined group. We also find that controlling for background variables actually increases the effect size and statistical significance of diagnosis of or treatment for a mental or emotional disorder. In Model 3, having been diagnosed with or treated for a psychological disorder increases the likelihood of discipline by 3.3 percent $(p<.05)$.

\section{Predictions and Goodness of Fit}

Our regression analyses show the predictive power of single variables on the likelihood of discipline. Yet bar examining authorities evaluate the totality of an

21. In alternative specifications (not reported) we used only one of LSAT score, law school GPA, and class rank to check for multicollinearity. When GPA and LSAT score are dropped, class rank becomes a statistically significant negative predictor of discipline risk $(p<.05)$. LSAT score is never significant, even when the other measures are excluded. 
TABLE 5.

"Hits" and "Misses" for In-Sample Predictions of Discipline Based on Model 3 of Table 4

\begin{tabular}{|c|c|c|c|c|}
\hline & & \multicolumn{3}{|c|}{ Predicted } \\
\hline & & Not Disciplined & Disciplined & Total \\
\hline \multirow{9}{*}{$\begin{array}{l}\bar{\sigma} \\
\text { 吾 }\end{array}$} & Not Disciplined & 1,198 & 0 & 1,198 \\
\hline & row $\%$ & $100.00 \%$ & $0.00 \%$ & $100.00 \%$ \\
\hline & column \% & $89.34 \%$ & $0.00 \%$ & $89.20 \%$ \\
\hline & Disciplined & 143 & 2 & 145 \\
\hline & row $\%$ & $98.62 \%$ & $1.38 \%$ & $100.00 \%$ \\
\hline & column \% & $10.66 \%$ & $100.00 \%$ & $10.80 \%$ \\
\hline & Total & 1,341 & 2 & 1,343 \\
\hline & row $\%$ & $99.85 \%$ & $0.15 \%$ & $100.00 \%$ \\
\hline & column \% & $100.00 \%$ & $100.00 \%$ & $100.00 \%$ \\
\hline
\end{tabular}

applicant's file: a single misdemeanor conviction might not be enough to raise red flags, yet someone with a misdemeanor conviction, multiple traffic violations, and law school discipline might be judged to lack good character.

Can the information gathered by bar authorities, when used in a statistically optimal way, allow for accurate predictions of who will subsequently receive discipline? To address that question, Table 5 shows the "hits" and "misses" associated with a simple prediction rule derived from the baseline specification in Model 3 of Table $4 .{ }^{22}$ For each observation, we obtain a predicted probability of discipline by feeding the values of all the explanatory variables for that observation into the estimated regression equation. Any observation for which the model estimates a probability of discipline greater than 50 percent is treated as a prediction of discipline; those observations for which the predicted probability of discipline is less than 50 percent are treated as predictions of no discipline. We are then in a position to ask how accurately the model predicts who will be disciplined and who will not. "Hits" are defined as correct predictions (either of discipline or no discipline); "misses" are incorrect predictions. Table 5 provides subtotals by row (row \%), indicating how many of those with a given actual outcome were (correctly) predicted to have that outcome and how many were (incorrectly) predicted not to have it. It also provides subtotals by column (column \%), indicating how many of those with a given predicted outcome actually had that outcome. ${ }^{23}$

Since such a small fraction of applicants is subsequently disciplined, the most naive plausible model would predict no discipline for anyone. That model would correctly

22. We also ran the predicted probabilities using Model 1 of Table 4. We had the same predictions as reported in Table 5: a correct prediction of 100 percent of the never-disciplined lawyers and a correct prediction 1.38 percent of the disciplined lawyers.

23. That is, for the first row, reading across: of the 1,198 total observations in our sample who did not receive discipline, the model correctly predicted 1,198 (100 percent) of them. For the first column, reading down (in italics): Of the 1,341 total observations that our model predicted would not receive discipline, 1,198 (89.34 percent) did not in fact receive discipline, while 143 (10.66 percent) did. 
predict 100 percent of the 1,198 never-disciplined lawyers (Row 1 of Table 5), but would fail to predict any of the 145 actual instances of discipline in Row 2 . The naïve model, however, makes for an obvious baseline against which to compare the predictive accuracy (goodness of fit) of our specification. As it turns out, our results do not provide much of an improvement over that baseline. As does the naïve model, our Model 3 correctly predicts 100 percent of the 1,198 never-disciplined lawyers. But we correctly predict only two ( 1.38 percent) of the 145 disciplined lawyers. In other words, when we use all the available character information in a statistically rigorous fashion, the payoff is only two more correct predictions for who will be disciplined than would be achieved through the naïve model that predicts no discipline for anyone. ${ }^{24}$

Another caution is in order. The model was estimated using a sample of roughly one-fifth of the never-disciplined lawyers and all those lawyers whose discipline we were able to uncover. ${ }^{25}$ This means that even if the model were applied to the entire population of admitted lawyers, there would be no more truly disciplined lawyers "left" to predict. It is possible that fitting the model to the entire population might (incorrectly) predict discipline for some of the never-disciplined lawyers who were not in our sample; but a larger sample of the never-disciplined lawyers cannot possibly increase the number of correct predictions of discipline, so our model represents the upper bound in terms of predicting who will be disciplined.

Figure 2 provides another way to understand the very modest predictive power of the admissions data. The figure plots the total number of applicants for each predicted probability of discipline, as well as the number who were actually disciplined. Importantly, 1,274 applicants (including 115 of the 145 who were subsequently disciplined) had predicted discipline probabilities that were less than 10 percent, and are not shown in the figure. Of the 68 applicants with predicted discipline probabilities greater than 10 percent, only thirty ( 43 percent) were actually disciplined. There are three clear outliers (with predicted probabilities of 43,61 , and 73 percent), but most of the applicants are clustered in the 10-20 percent range, and only fifteen applicants had predicted probabilities above 20 percent. The figure makes it quite clear that there is no significant group of high-risk applicants who stand out from the rest of their peers.

\section{Differences Between Severely, Less Severely, and Never-Disciplined Lawyers}

The analysis thus far assumes that all discipline is identical and that the appropriate distinction to be drawn is between the disciplined and the never-disciplined lawyers. But there may be good reasons to distinguish between different types of discipline. Predicting which lawyers will be disbarred for stealing client funds is not necessarily the same thing

24. One could also frame these issues in a different way: of the 1,341 predictions of no-discipline made by our model, 89.34 percent $(1,198)$ are correct. However, there are 143 instances of discipline that we miss (false negatives). The model's two predictions of discipline are also correct, so there are no false positives. Of course, this accuracy comes at a cost of failing to predict almost all of those who will receive discipline, and again represents virtually no improvement over the naïve baseline model.

25. We dropped seven disciplined lawyers with missing application files and we may be missing some private discipline for those lawyers who were also admitted in states that make use of it. That said, we have the complete set of all lawyers whose disciplinary status can be known with certainty. 


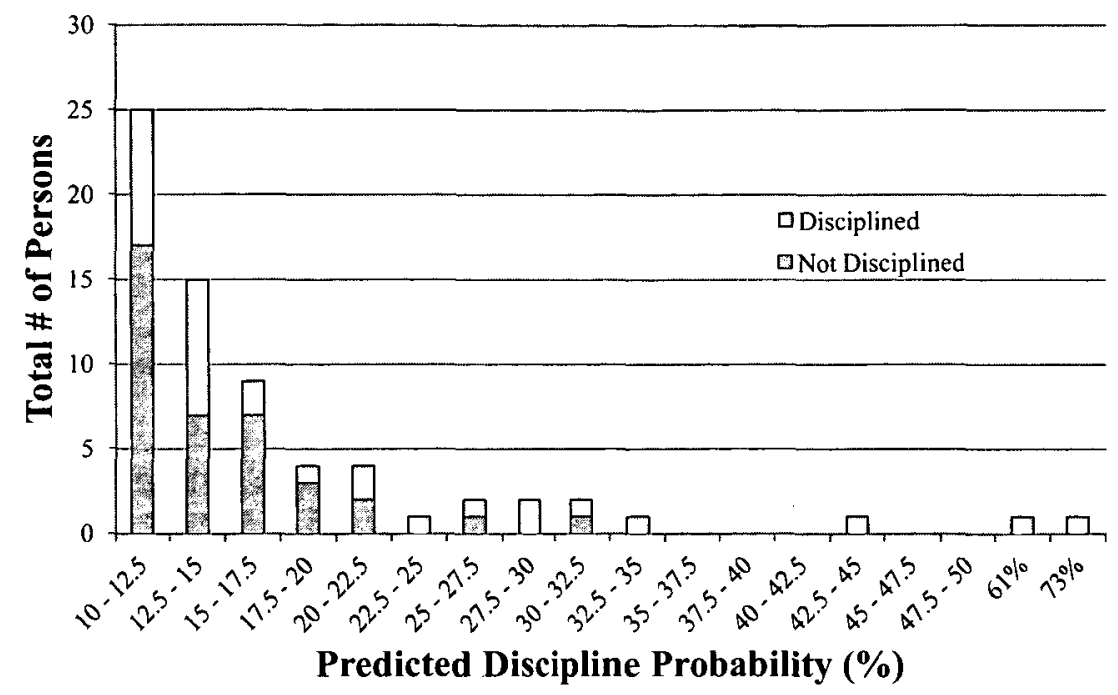

FIGURE 2.

\section{Predicted Probabilities of Discipline}

as predicting which lawyers will be subject to censure for minor record-keeping violations. In this section, we briefly present evidence on differences between the severely and less severely disciplined lawyers. We then use multinomial regression techniques to test whether the factors that predict severe discipline also predict less severe discipline.

When we divide our sample by the severity of discipline imposed, a surprising result emerges: the severely disciplined group looks somewhat more like the neverdisciplined group than like the lawyers who were less severely disciplined. In other words, the explanatory variables are more strongly associated with less severe discipline than with severe discipline.

The severely disciplined lawyers were academically somewhat stronger than those who were less severely disciplined. For example, 63.7 percent of the less severely disciplined lawyers attended a law school ranked in the bottom half as opposed to 51.8 percent of the severely disciplined lawyers. About 11 percent of the severely disciplined lawyers failed the Connecticut bar exam at least once before being admitted, but that figure rises to just under 17 percent for the less severely disciplined group (results not shown) (see Levin, Zozula, and Siegelman 2013).

Roughly the same pattern emerges for nonacademic variables. The less severely disciplined group had more lawyers with delinquent credit accounts, 26.4 percent, as compared to 19.6 percent of the severely disciplined lawyers, and 7.2 percent of the never-disciplined group. Perhaps surprisingly, there were no reported instances of mental health diagnosis/treatment or substance dependency/treatment among those applicants who later received severe discipline. The less severely disciplined group was the only disciplined group to reveal mental health (6.7 percent) and substance dependency ( 2 percent) issues.

However, the severely disciplined group does differ from the less severely disciplined group on certain variables we would associate with a greater likelihood of discipline. Women were a smaller share of the severely disciplined than of the less severely 
disciplined group (12.5 percent vs. 19.1 percent). The severely disciplined group had a higher rate of criminal convictions ( 7.1 percent vs. 4.6 percent) and driver's license suspensions ( 17.9 percent vs. 10.1 percent). Both groups reported more convictions and license suspensions than those who were never disciplined (compare Figures 1 and 3 ).

We now seek to answer two questions: First, what explains each type of discipline and, second, are these factors the same across the two discipline types? We use multinomial logistic regression, in which the dependent variable can take on one of three possible outcomes: no discipline $(Y=0)$, less severe discipline $(Y=1)$, and severe discipline $(Y=2) .{ }^{26}$ The coefficients estimated from this regression give the probability of moving from the baseline condition (no discipline) to either of the other two states, so there are thus two coefficients for each explanatory variable. ${ }^{27}$ The coefficients are estimated jointly via maximum likelihood methods. We then test for whether the estimated coefficients predicting less severe discipline are the same as those predicting severe discipline, which is equivalent to asking whether we are justified in using a single logistic equation to explain both types simultaneously or whether we need a separate equation for each discipline type.

Disaggregating by severity of discipline (Table 6) reveals some interesting similarities and differences from earlier models that treated all discipline as homogenous. Being female still has a large and statistically significant (negative) effect on the likelihood of both severe and less severe discipline, just as it did in the earlier regressions that combined these two types of discipline. But some effects do differ once we disaggregate. Having experienced prior discipline (as a lawyer in another state before applying to the Connecticut bar) had an insignificant effect on the likelihood of discipline in most of the logistic models of Table 4. Prior bar discipline continues to have no effect on the probability of receiving less severe discipline in Table 6 ; but, surprisingly, it appears to reduce the likelihood of receiving severe discipline $(p<0.01)$, as shown in Column 2 . In Table 4, we saw that attending a lower-ranked law school was associated with an increased likelihood of discipline overall, but once we disaggregate, law school rank retains its explanatory power only for less severe discipline-the prestige of the law school attended has no effect on the likelihood of receiving severe discipline. Higher law school grades reduce the likelihood of less severe discipline, but have no effect on severe discipline.

Perhaps the most significant finding in Table 6 is the difference that a reported preapplication mental health diagnosis/treatment makes for the likelihood of receiving the two types of discipline. Consistent with our earlier findings, having had a mental health diagnosis/treatment history significantly raises the probability that an applicant will receive less severe discipline. However, it actually lowers the likelihood of receiving severe discipline, by a large and significant amount. A similar pattern emerges for

26. We recognize that the model sacrifices some statistical power by ignoring the fact that the choices are ordered: less severe discipline is obviously "less severe" than "severe" discipline, but the (unordered) multinomial model does not make use of this information. We were unable to discover an econometric test for pooling in an ordered multinomial model, however, so we use the unordered version instead.

27. In other words, given variables indexed by $i=1, \ldots, k$, and disciplinary status indexed by 1 or 2 , $\beta_{i, 1}$ represents the effect of a one unit change in explanatory variable $i$ (say, amount of debt) on the probability of receiving discipline of type 1 (say, less severe). $\beta_{i, 2}$ represents the effect of a one unit change in that same explanatory variable on the probability of receiving discipline of type 2 . 


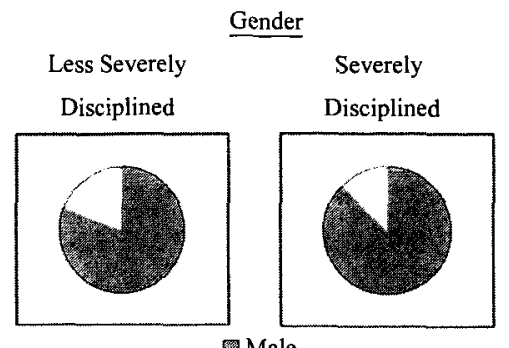

Male

c Female

Driver's License Suspension

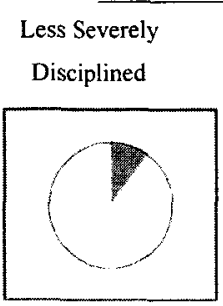

Driver's License Suspension

$\square$ No Driver's License Suspension

Criminal Conviction
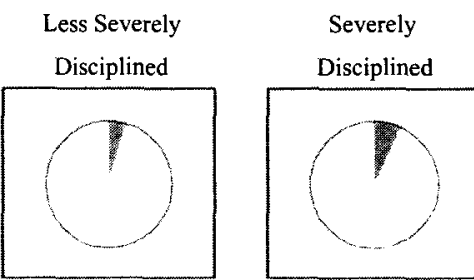

중 Criminal Conviction

[] No Criminal Conviction

Mental or Emotional Disorders

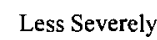

Disciplined

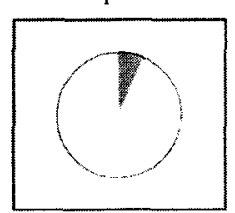

通 Mental or Emotional Disorder

$\square$ No Mental or Emotional Disorder
Rank of Law School

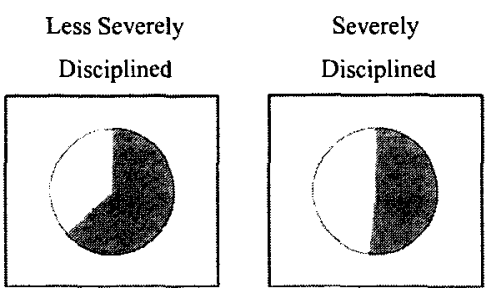

Bottom $50 \%$

DTop $50 \%$

Traffic Violations

Less Severely Severely

Disciplined Disciplined

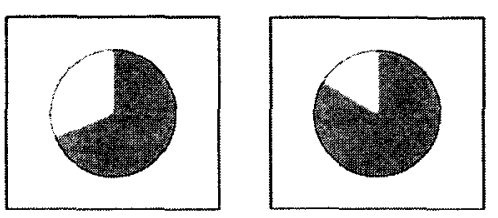

图 Traffic Violations

$\square$ No Traffic Violations

Delinquent Accounts

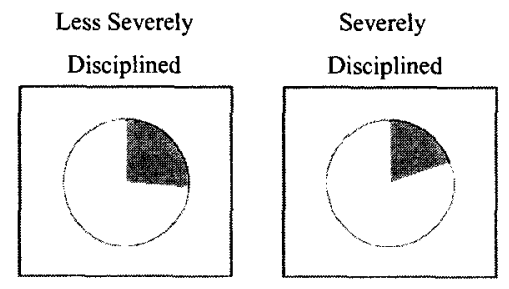

国 Delinquent Accounts

DNo Delinquent Accounts

Substance Abuse

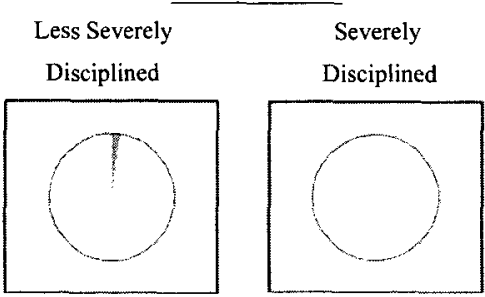

Substance Abuse

$\square$ No Substance Abuse

FIGURE 3.

Differences Between Less Severely Disciplined and Severely Disciplined Lawyers

substance dependency/treatment and for bankruptcy: both significantly lower the risk of severe discipline but have no effect on less severe discipline.

We observe differential effects for several other variables as well. Student debt, the number of traffic violations, and being a party to civil litigation are positively correlated with less severe discipline, but not with severe discipline. Having a criminal conviction 
TABLE 6.

Multinomial Logistic Regression Simultaneously Predicting Both Types of Discipline; Marginal Effects Specification

\begin{tabular}{|c|c|c|}
\hline & $\begin{array}{l}\text { Less Severely } \\
\text { Disciplined }\end{array}$ & $\begin{array}{l}\text { Severely } \\
\text { Disciplined }\end{array}$ \\
\hline \multicolumn{3}{|l|}{ Character Variables } \\
\hline Prior Discipline & $\begin{array}{c}0.2900 \\
(4.3920)\end{array}$ & $\begin{array}{l}-26.4400^{* * *} \\
(4.6220)\end{array}$ \\
\hline Discipline, Academic Deficiency & $\begin{array}{l}-0.0032 \\
(0.0062)\end{array}$ & $\begin{array}{l}-0.0073 \\
(0.0060)\end{array}$ \\
\hline Discipline, Other & $\begin{array}{l}-0.0581^{* * *} \\
(0.0176)\end{array}$ & $\begin{array}{c}0.0085 \\
(0.0086)\end{array}$ \\
\hline $\begin{array}{l}\text { Negative Feedback, Dean's } \\
\text { Certificate }\end{array}$ & $\begin{array}{l}0.2310^{* * *} \\
(0.0684)\end{array}$ & $\begin{array}{l}-8.1390 * * * \\
(1.2310)\end{array}$ \\
\hline Negative Feedback, Letters & $\begin{array}{l}-0.0002 \\
(0.0070)\end{array}$ & $\begin{array}{l}-0.0057 \\
(0.0077)\end{array}$ \\
\hline Work Discipline & $\begin{array}{c}0.0032 \\
(0.0047)\end{array}$ & $\begin{array}{c}0.0020 \\
(0.0041)\end{array}$ \\
\hline Default on Student Loan & $\begin{array}{c}0.0059 \\
(0.0080)\end{array}$ & $\begin{array}{l}-0.0011 \\
(0.0071)\end{array}$ \\
\hline Judgment Against by Creditor & $\begin{array}{c}0.0006 \\
(0.0091)\end{array}$ & $\begin{array}{c}-0.0052 \\
(0.0100)\end{array}$ \\
\hline Delinquent Accounts & $\begin{array}{l}0.0164^{* * * *} \\
(0.0048)\end{array}$ & $\begin{array}{c}0.0068^{*} \\
(0.0036)\end{array}$ \\
\hline Bankruptcies & $\begin{array}{r}1.6390 \\
(4.347)\end{array}$ & $\begin{array}{l}-36.0800 * * * \\
(6.2990)\end{array}$ \\
\hline Non-Student Loan Debt & $\begin{array}{l}.0000 \\
(.0000)\end{array}$ & $\begin{array}{l}.0000 \\
(.0000)\end{array}$ \\
\hline Student Loan Debt & $\begin{array}{l}0.0002^{* * *} \\
(.0001)\end{array}$ & $\begin{array}{l}0.0001 * * \\
(.0001)\end{array}$ \\
\hline Criminal Convictions & $\begin{array}{l}-0.0003 \\
(0.0102)\end{array}$ & $\begin{array}{r}0.0113 * \\
(0.0060)\end{array}$ \\
\hline Traffic Violations, Number & $\begin{array}{r}0.0018^{*} \\
(0.0010)\end{array}$ & $\begin{array}{c}0.0007 \\
(0.0009)\end{array}$ \\
\hline Driver's License Suspensions & $\begin{array}{l}-0.0069 \\
(0.0063)\end{array}$ & $\begin{array}{r}0.0079^{*} \\
(0.0047)\end{array}$ \\
\hline Civil Litigation & $\begin{array}{l}0.0109^{* * * *} \\
(0.0040)\end{array}$ & $\begin{array}{c}0.0031 \\
(0.0040)\end{array}$ \\
\hline \multicolumn{3}{|l|}{ Character Variables, continued } \\
\hline Litigation Alleging Fraud & $\begin{array}{l}0.4400 * * * \\
(0.1260)\end{array}$ & $\begin{array}{c}-14.2600 * * * \\
(2.38700)\end{array}$ \\
\hline Substance Abuse & $\begin{array}{c}0.0083 \\
(0.0144)\end{array}$ & $\begin{array}{l}-0.1850 * * * \\
(0.0264)\end{array}$ \\
\hline Mental or Emotional Disorder & $\begin{array}{l}0.159 * * * \\
(0.0432)\end{array}$ & $\begin{array}{l}-4.3900^{* * *} \\
(0.8410)\end{array}$ \\
\hline \multicolumn{3}{|l|}{ Demographic Variables } \\
\hline Age & $\begin{array}{c}.0001 \\
(0.0002)\end{array}$ & $\begin{array}{c}.0000 \\
(0.0003)\end{array}$ \\
\hline Female & $\begin{array}{l}-0.0127^{* * *} \\
(0.0030)\end{array}$ & $\begin{array}{l}-0.0102 * * * \\
(0.0023)\end{array}$ \\
\hline
\end{tabular}


TABLE 6.

(Continued)

\begin{tabular}{lcc}
\hline & $\begin{array}{c}\text { Less Severely } \\
\text { Disciplined }\end{array}$ & $\begin{array}{c}\text { Severely } \\
\text { Disciplined }\end{array}$ \\
\hline 1989 & -0.0021 & -0.0001 \\
& $(0.0045)$ & $(0.0038)$ \\
1990 & -0.0014 & -0.0008 \\
& $(0.0044)$ & $(0.0037)$ \\
1991 & -0.0046 & 0.0025 \\
& $(0.0041)$ & $(0.0039)$ \\
Prior Application & 0.0076 & 0.0027 \\
& $(0.0054)$ & $(0.0051)$ \\
Waived In & -0.0082 & 0.0046 \\
& $(0.0054)$ & $(0.0089)$ \\
Armed Services & 0.0032 & -0.0002 \\
& $(0.0071)$ & $(0.0048)$ \\
Law School Ranked Bottom & $0.0113 * * *$ & 0.0045 \\
$50 \%$ & $(0.0040)$ & $(0.0033)$ \\
Class Rank & -0.0060 & -0.0024 \\
& $(0.0101)$ & $(0.0074)$ \\
Average Grade & $-0.0039^{* * *}$ & -0.0005 \\
& $(0.0015)$ & $(0.0011)$ \\
LSAT (percentile) & 0.0053 & 0.0001 \\
& $(0.0109)$ & $(0.0097)$ \\
N & 1,343 & 1,343 \\
\hline
\end{tabular}

$* * * \mathrm{p}<0.01, * * \mathrm{p}<0.05, * \mathrm{p}<0.1$. Standard errors in parentheses. Missing mean substitution. All variables held at mean. Coefficients are marginal effects which measure the change in likelihood of discipline given a one unit change in the independent variable.

at the time of application is weakly associated with a greater risk of severe discipline, but does not change the probability of receiving less severe discipline.

It is difficult to see a pattern or explanation for these differential effects. Even if we cannot explain them, however, we can formally test whether the results of Table 6 are consistent with using a single discipline measure (as in Table 4) or whether we need to use separate equations for each of the two discipline types (as in Table 6). To do so, we use a test for pooling in multinomial logit models. ${ }^{28}$ The basic logic of this test is simple. If severe and less severe discipline respond similarly to the independent variables, there is little or nothing to be "lost" by combining the two into a single dependent variable ("discipline"). On the other hand, if the regression performs significantly less well as a single logistic regression than it does when we disaggregate by discipline type, then aggregation is rejected by the data. We find-using the standard Wald test-that pooling is strongly rejected. ${ }^{29}$ This implies that, overall, the two types of discipline are

28. The technique was devised by Jan Cramer and Geert Ridder (1991) and the method is described in their article.

29. The test statistic is $\chi^{2}{ }_{(6)}$ with a value of 4516.56 , for a $p$ value of 0.00 . 
sufficiently different in the ways they respond to the independent variables that we are not justified in combining them into a single measure.

\section{DISCUSSION}

The results presented above demonstrate that some factors known to the bar authorities at the time a bar candidate applies for admission are robustly associated with a greater chance that the applicant will go on to be disciplined. But three important qualifications are required.

First, variables such as gender are statistically significant and do have a "large" effect on the probability of discipline. Nevertheless, the baseline probability of discipline is so low that even something that doubles this probability-say, from 3 percent to 6 percent - does not provide much predictive leverage. Policy makers would almost certainly not be advised to take significant action based on a predicted probability of future discipline as low as 6 percent. Thus, even though we can be confident that men are substantially more likely to be disciplined than women (controlling for other observable factors), this knowledge is not very useful in making admissions decisions. The same logic applies for all the other statistically significant effects we found.

Second, our model suggests that there are at least two distinct types of discipline (severe and less severe), and that they respond differently to many of the independent variables we considered. Variables such as substance dependency, the number of traffic violations, criminal convictions, and having had a preapplication psychological diagnosis/treatment have differential effects on the risk of receiving severe and less severe discipline. Although the bar examining committee may seek to prevent all types of lawyer misconduct, distinguishing between lawyers who receive less severe and more severe discipline may be a useful way to think about allocating resources.

Finally, the analysis presented so far has focused exclusively on prediction, without any attempt to elucidate the causal mechanisms linking the explanatory variables and the imposition of discipline. Given the limitations of the available data, we believe this focus is unavoidable. Nevertheless, we think it is worth hypothesizing about the possible causal mechanisms at play.

\section{Some Possible Causal Explanations}

Why do the explanatory variables predict either kind of discipline? We find that many of the variables that are associated with increased discipline risk are demographic

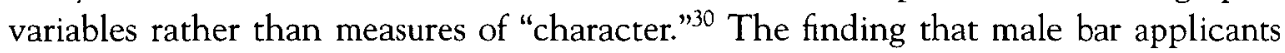
were significantly more likely to be disciplined than female applicants replicates similar findings in the United States, Canada, and Australia (Arnold 1998; Curtis and

30. This result is in accord with what social psychologists, following Ross (1977), describe as the "fundamental attribution error." Lay persons tend to ascribe an individual's behavior to robust, situationinvariant character traits, whereas research in social psychology lays much more emphasis on context and setting as explanations for behavior. 
Kaufman 2003-2004; Haller and Green 2008) and is consistent with a large body of evidence about deviance generally. This finding is interesting because women are more likely to work in solo practices than men (Carson 2012, 10) and are more likely to experience depression (Hagan and Kay 2007). Thus, other things being equal, women should be more susceptible to grievances and discipline. The reasons for the gender differences are unclear. It is possible that women are more conscientious than men (Schmitt 2008), which might mean that they are less likely to be subject to discipline. It may be that women are more risk averse than men (Byrnes et al. 1999) and are less likely to take moral risks for money (Furnham and Okamura 1999). Female lawyers who work in firms may have less contact with clients than their male counterparts, which may present fewer opportunities for them to be grieved by clients (Bartlett 2008). It is also possible that female lawyers are more conciliatory when clients become dissatisfied, making women less likely to be the subject of grievances. Alternatively, women may be more cooperative with disciplinary authorities than men (Hatamyar and Simmons 2004,828 ) and thus less likely to engage in some of the behaviors (e.g., verbal attacks on disciplinary authorities, refusals to admit wrongdoing, etc.) that result in sanctions that could have been avoided (Abel 2008).

One possible explanation for the gender difference in discipline that our data do not seem to support is that women were less likely to continue in the practice of law than were men. If men have more years of exposure to discipline risk than women, they will be more likely to experience discipline at some point, even if the annual discipline risk is the same for both genders. In fact, however, our data show that on average, women practiced only two fewer months than men. This slight difference is too small to explain the observed gender difference in likelihood of discipline. We cannot discount the possibility, however, that some women were not working full time, which would lower their exposure to discipline risk. ${ }^{31}$

We argue that academic performance variables, such as law school prestige and law school grades, predict discipline risk, at least in part, through career trajectory. Other studies have shown that lawyers who graduate from top-tier schools and who do well in law school are more likely to go to large firms, while lawyers who graduate from lower-tier schools and those with lower grades are more likely to work in solo and small firm practice (Zemans and Rosenblum 1981; Abel 1989; Heinz et al. 2005; Dinovitzer et al. 2009). Solo and small-firm lawyers are more likely to be disciplined and lawyers in such settings are often disciplined for relatively low-level acts of omission (e.g., neglect of client matters, failure to return phone calls) that may be due to inadequate office support. By contrast, more serious misconduct, such as theft of client funds or other crimes, occurs both in solo firms and in more elite practice settings (Lerman 1999). This explanation is consistent with our findings linking rank of law school and law school grades to less severe discipline, but not to severe discipline. Academic measures such as rank of law school attended and law school grades, then, may be predicting discipline "indirectly," via their link to practice setting.

31. We measured length of practice by looking at how long a lawyer remained registered as an "active" member of any bar. Some women (and some men) might have retained "active" status when not practicing full time or when not actually practicing at all, so the two-month figure may underestimate the true difference in career length. 
The results indicating that bar applicants with delinquent credit accounts or with higher student debt load are more likely to be subject to discipline may have a similar explanation. It may be that delinquent account holders have problems managing their paperwork or may not take their legal obligations seriously. ${ }^{32}$ If so, it is easy to imagine how such traits might lead to misconduct and subsequent discipline. An alternative explanation, however, is that bar applicants with delinquent credit accounts and higher debt may come from lower socioeconomic backgrounds. We know, for example, that graduates of elite law schools are more likely to come from higher socioeconomic backgrounds and to work in the largest firms (Heinz et al. 2005). These individuals may also need to incur less student debt than other applicants in order to attend college and law school..$^{33}$ Therefore, credit measures may also be predictive of discipline through the intervening variables of career trajectory and firm size.

The finding that those who reported a mental health diagnosis or treatment on their bar applications were more likely to be disciplined must be interpreted with caution. The types of diagnoses that applicants revealed were primarily anxiety disorders or depression associated with a stressful life event (e.g., divorce, death of a loved one). Only twenty-nine lawyers in the sample reported any prior diagnosis of a psychological disorder and/or treatment at the time of bar application, which is well below what would be expected in that population (Temple 2012). Those who experienced a psychological problem and failed to report it may have done so for reasons related to the likelihood of future discipline. For example, suppose the "nonreporters" were the least "truthful" among all those who experienced mental health problems and would thus be more likely than the "reporters" to experience future discipline. In that case, the coefficient that measures the effect of reporting a mental health diagnosis/treatment would understate the true effects of a mental health problem on the likelihood of future discipline. On the other hand, perhaps the "nonreporters" were those who experienced the mildest mental health problems, which might make them less likely than the reporters to be disciplined in the future. In that case, the true effect of experiencing a mental health problem on future discipline would be smaller than actually measured in the regression. The key point is that depending on the reasons for underreporting, the measured coefficient could be either too large or too small, and both possibilities are plausible.

Six of the twenty-nine lawyers who reported mental health diagnosis/treatment were subsequently disciplined (all less severely), although none of them indicated on their bar applications that their psychiatric condition was serious (e.g., involved a hospitalization). Moreover, five of the six disciplined lawyers incurred only one

32. We also looked at the possibility that higher nonstudent or student debt is linked to financial misconduct as a lawyer. This might be true if those with higher amounts of debt face greater financial pressures that lead them to steal money from clients or engage in other money-related misconduct. In fact, however, we found that debt levels were less predictive of discipline for money-related misconduct than of discipline generally, so there is no evidence of this financial pressure effect.

33. In other analyses (results not shown), we tested if the amount of student loan debt affected the likelihood of discipline differentially by rank of law school attended. The effect was very small in magnitude and not statistically significant. The inclusion of the interaction term did not alter the coefficients or significance of student debt and law school rank. 
disciplinary sanction and it was a reprimand. None of these five claimed that their prior psychological problems contributed to the conduct that led to discipline, although two referred to other stressors in their lives during the discipline proceedings (e.g., family or personal illnesses). Five of the six disciplined lawyers who revealed mental health diagnosis/treatment on their bar applications did not receive the grievance leading to discipline until more than ten years after admission. In other words, the data suggest that a reported history of mental health diagnosis/treatment on the bar application predicts, at best, low-level misconduct that is unlikely to occur until more than a decade after the applicant enters practice.

\section{Additional Caveats}

A few final caveats are in order. This study is small and is limited to a single state that is positioned between two major metropolitan areas. As a result, a majority of the lawyers in the study were also admitted in other jurisdictions and many practiced outside of Connecticut, so the group may not be representative of lawyers in other jurisdictions. Moreover, while we feel confident that we located all public discipline imposed on the lawyers admitted to the Connecticut bar from 1989-1992, it is possible that we failed to learn about out-of-state private discipline imposed on one or more lawyers for minor misconduct. (For an explanation of why we think this does not pose significant problems for interpreting our results, see Levin, Zozula, and Siegelman 2013, Appendix B.)

In addition, we only tracked admitted lawyers for seventeen to twenty years from the date of their admission to the Connecticut bar. If we had tracked all of these lawyers until the end of their careers, we might have obtained somewhat different results.

Finally, this study necessarily only relied on information that was reported to the CBEC when it made its admissions decision and as a result, the information may not fully reflect an applicant's true history. Although some of this information could be cross-verified (e.g., through dean's certificates, traffic records, and credit reports), it may be that lawyers who were disciplined were less likely to self-report certain problem history. For example, applicants with a history of hard-to-discover problems - such as substance abuse-may not have revealed this information on the bar application. Thus, the study only reflects the predictive value of the information that is disclosed to the bar examiners, and not the predictive value of applicants' true personal histories.

\section{CONCLUSION}

The information collected during the character and fitness inquiry does not appear to be very useful in predicting subsequent lawyer discipline. The reason is that the baseline likelihood of discipline among admitted lawyers is so low (about 2.5 percent of the lawyers in our cohort). Thus, even something-such as being male-that doubles the likelihood of subsequent disciplinary action only raises the probability of discipline to 5 percent. It seems unlikely that a regulator would deny admission to an applicant 
who had only a 5 percent chance of subsequent discipline, especially when the discipline would likely be a single reprimand. To meet even a modest "more-likely-than-not" standard, one would need to identify a set of variables that together raise the risk of discipline by a factor of twenty. In the data and models we examined, only two individuals were predicted to have a better than even chance of being disciplined, a finding that casts serious doubt on the usefulness of the character and fitness inquiry as a predictor of lawyer misconduct.

This preliminary study raises a number of questions for further research. First, and most obviously, there is the question of whether the study's findings can be replicated in other jurisdictions. It is also important to determine whether the results remain the same if the discipline histories of lawyers are traced for more than twenty years. Demographic variables that may have an impact on the likelihood of lawyer discipline-such as socioeconomic status and race-should be incorporated into the analysis (although their use in admissions decisions would raise serious equal protection problems). The significance of debt burden may merit special inquiry. It will also be important to look at whether the effects we observed are maintained when controlling for practice setting, which we could not do in this analysis, but that would be feasible with a longitudinal panel study. Of course, information such as practice setting is not available to committees at the time an admission decision is made; but this post-admission information would be useful in sorting out whether the effects of background variables on discipline are mediated through the setting in which a lawyer practices.

If the predictive value of the information obtained during the character and fitness inquiry is low, are there other good reasons to continue the requirement? As previously noted, protection of the public is the primary justification for the inquiry and it is possible that the mere existence of the process discourages certain bad actors from ever applying to law school. However, it may also deter those with a history of relatively minor misconduct, with a disparate impact on racial and ethnic minorities. The extent to which this actually occurs needs to be explored.

The character and fitness inquiry may also serve symbolic functions. It could assure the public that there are safeguards on who becomes a lawyer, thus promoting public trust in the profession. The inquiry may also serve as a socialization process for new lawyers, signaling that they are expected to display "good character" throughout their careers, for example, by avoiding substance dependency or criminal judgments. These symbolic capacities of the character and fitness inquiry might be important enough to justify the continued use of at least some of the questions, despite their predictive infirmities. While our study cannot speak to the symbolic importance of the character and fitness inquiry, it would be useful to evaluate the public's and bar applicants' attitudes toward the requirement, rather than simply assume that these symbolic functions are worth the time and energy devoted to the character and fitness inquiry.

Should the character and fitness inquiry be continued in its current form? Too many other questions remain open to answer that one at this time. Nevertheless, it is not too soon to ask serious questions about the narrow range of permissible actions that regulatory authorities can take in response to the information in candidates' admission files. As it now stands, authorities must choose from an extremely limited menu of responses to an individual's application: they can deny admission altogether- 
something they almost never do-or they can admit the applicant. Some states also grant conditional admission, which permits monitoring of certain applicants for a relatively short time. ${ }^{34}$ This response may be misguided if, as the data suggest, the initial grievance leading to discipline is, on average, not filed until a lawyer has been in practice for more than ten years.

Future work should consider the possibility of other alternatives. Even if we cannot accurately distinguish lawyers who will subsequently experience discipline from those who will not, it might be appropriate for admissions authorities to impose some kind of additional requirements on applicants with a statistically elevated risk of future discipline. For example, someone with an elevated discipline risk (say, a 20 percent chance of future discipline) might be required to maintain malpractice insurance as a condition of admission or might be required to take a course in law office management if he or she ever practices in a solo or small firm. Lawyers with an elevated risk of severe discipline might be subject to random audits of client trust accounts. Even though it is difficult to predict which applicants will later be sanctioned, there might be room to impose some prudential requirements on those applicants who pose a higher-than-average risk of future discipline.

\section{REFERENCES}

Abel, Richard L. 1989. American Lawyers. New York: Oxford University Press.

- 2008. Lawyers in the Dock: Learning from New York Disciplinary Proceedings. New York: Oxford University Press.

Allan, Rick B. 1997. Alcoholism, Drug Abuse and Lawyers: Are We Ready to Address the Denial? Creighton Law Review 31:265-77.

American Bar Association (ABA). 2010. 2009 Survey on Lawyer Discipline Systems (S.O.L.D). Chicago: ABA.

Arnold, Bruce. 1998. A Life Course Dynamics Approach to Professional Deviance and SelfRegulation: The Case of Ontario Lawyers. PhD diss., University of Toronto.

Auerbach, Jerold S. 1976. Unequal Justice: Lawyers and Social Change in Modern America. New York: Oxford University Press.

Baer, Carl, and Peg Corneille. 1992. Character and Fitness Inquiry: From Bar Admission to Professional Discipline. Bar Examiner 61 (4): 5-12.

Bartlett, Francesca. 2008. Professional Discipline Against Female Lawyers in Queensland: A Gendered Analysis. Griffith Law Review 17:301-29.

Bauer, Jon. 2001. The Character of the Questions and the Fitness of the Process: Mental Health, Bar Admissions, and the Americans with Disabilities Act. UCLA Law Review 49:93-224.

Benjamin, G. H. Andrew, Elaine J. Darling, and Bruce Sales. 1990. The Prevalence of Depression, Alcohol Abuse, and Cocaine Abuse Among United States Lawyers. International Journal of Law \& Psychiatry 13:233-46.

Byrnes, James P., David C. Miller, and William D. Schafer. 1999. Gender Differences in Risk-Taking: A Meta-Analysis. Psychological Bulletin 125 (3): 367-83.

34. More than twenty states have conditional admission programs that allow them to attach conditions to admission of candidates as a type of probationary admission (Denzel 2011). The maximum length of conditional admission in many states is twenty-four months. See ABA Model Rule on Conditional Admission to Practice Rule 4 Commentary, http://www.americanbar.org/content/dam/aba/migrated/ legalservices/downloads/colap/ABAModelRule_ConditionalAdmission_Feb2008.authcheckdam.pdf. 
Carlin, Jerome E. 1966. Lawyers' Ethics: A Survey of the New York City Bar. New York: Russell Sage Foundation.

Carson, Clara N. 2012. Lawyer Statistical Report: The U.S. Legal Profession in 2005. Chicago: American Bar Foundation.

Chambliss, Elizabeth. 2005. The Nirvana Fallacy in Law Firm Regulation Debate. Fordham Urban Law Joumal 33:119-51.

Clarke, Jennifer C. 1995. Conditional Admission of Applicants to the Bar: Protecting Public and Private Interests. Bar Examiner 64 (2): 53-69.

Coleman, Phyllis, and Ronald A. Shellow. 1994. Ask About Conduct, Not Mental Illness: A Proposal for Bar Examiners and Medical Boards to Comply with the ADA and the Constitution. Joumal of Legislation 20:147-77.

Corneille, Margaret Fuller. 2001. Bar Admissions: New Opportunities to Enhance Professionalism. South Carolina Law Review 52:609-20.

Covington, Stephanie S., and Barbara E. Bloom. 2003. Gendered Justice: Women in the Criminal Justice System. In Gendered Justice: Addressing Female Offenders, ed. Barbara E. Bloom, 3-24. Durham, NC: Carolina Academic Press.

Cramer, Jan S., and Geert Ridder. 1991. Pooling States in the Multinomial Logit Model. Journal of Econometrics 47:267-72.

Cunningham, M. A. 1992. The Professional Image Standard: An Untold Standard of Admission to the Bar. Tulane Law Review 66:1015-43.

Curtis, Debra Moss, and Billy Jo Kaufman. 2003-2004. A Public View of Attorney Discipline in Florida: Statistics, Commentary, and Analysis of Disciplinary Actions Against Licensed Attorneys in the State of Florida from 1988-2002. Nova Law Review 28:669-719.

Denzel, Stephanie. 2011. Second-Class Licensure: The Use of Conditional Admission Programs for Bar Applicants with Mental Health and Substance Abuse Issues. Connecticut Law Review 43:891930.

Dinovitzer, Ronit, Robert L. Nelson, Gabriele Plickert, Rebecca Sandefur, and Joyce Sterling. 2009. After the JD II: Second Results from a National Survey of Legal Careers. Chicago: American Bar Foundation and NALP.

Dzienkowski, John S. 2004. Character and Fitness Inquiries in Law School Admissions. South Texas Law Review 45:921-82.

Fortney, Susan Saab. 2004. Law School Admissions and Ethics-Rethinking Character and Fitness Inquiries. South Texas Law Review 45:983-96.

Furnham, Adrian, and Ryo Okamura. 1999. Your Money or Your Life: Behavioral and Emotional Predictors of Money Pathology. Human Relations 52:1157-77.

Gordon, Robert W. 2002. The Legal Profession. In Looking Back at Law's Century, ed. Austin Sarat, Bryant Garth, and Robert A. Kagan, 288-331. Ithaca, NY: Cornell University Press.

Hagan, John, and Fiona Kay. 2007. Even Lawyers Get the Blues: Gender, Depression, and Job Satisfaction in Legal Practice. Law 83 Society Review 41:51-77.

Haller, Linda, and Heather J. Green. 2008. Solicitors' Swan Song?: A Statistical Update on Lawyer Discipline in Queensland. Bond Law Review 19:140-67.

Hatamyar, Patricia W., and Kenneth M. Simmons. 2004. Are Women More Ethical Lawyers? An Empirical Study. Florida State University Law Review 31:785-853.

Heinz, John P., Robert L. Nelson, Rebecca L. Sandefur, and Edward O. Laumann. 2005. Urban Lawyers: The New Social Structure of the Bar. Chicago: University of Chicago Press.

Hoener, Sonya. 2008. Due Process Implications of the Rehabilitation Requirement in Character and Fitness Determinations in Bar Admissions. Whittier Law Review 29:829-56.

Langford, Carol M. 2005. The Changing Structure of American Law Firms: Depression, Substance Abuse, and Intellectual Property Lawyers. University of Kansas Law Review 53:875947.

Larson, Magali Sarfatti. 1977. The Rise of Professionalism: A Sociological Analysis. Berkeley: University of California Press.

Law Services. 1991. The Law School Admission Test: Sources, Contents, and Uses. Newtown, PA: Law School Admission Services. 
Lerman, Lisa G. 1999. Blue Chip Bilking: Regulation of Billing and Expense Fraud by Lawyers. Georgetown Journal of Legal Ethics 12:205-366.

Levin, Leslie C. 2004. The Ethical World of Solo and Small Law Firm Practitioners. Houston Law Review 41:309-92.

Levin, Leslie C., Christine Zozula, and Peter Siegelman. 2013. A Study of the Relationship Between Bar Admissions Data and Subsequent Lawyer Discipline. Newtown, PA: Law School Admissions Council.

Long, J. Scott. 1997. Regression Models for Categorical and Limited Dependent Variables. Thousand Oaks, CA: Sage.

Mather, Lynn, and Leslie C. Levin. 2012. Why Context Matters. In Lawyers in Practice: Ethical Decision Making in Context, ed. Leslie C. Levin and Lynn Mather, 3-24. Chicago: University of Chicago Press.

Mather, Lynn, and Craig A. McEwen. 2012. Client Grievances and Lawyer Conduct: The Challenges of Divorce Practice. In Lawyers in Practice: Ethical Decision Making in Context, ed. Leslie C. Levin and Lynn Mather, 63-86. Chicago: University of Chicago Press.

Mather, Lynn, Craig A. McEwen, and Richard J. Maiman. 2001. Divorce Lawyers at Work: Varieties of Professionalism in Practice. New York: Oxford University Press.

Missouri Board of Law Examiners. 2011. Frequently Asked Questions (FAQs). https://www.mble.org/ faq\#360 (accessed June 24, 2013).

National Conference of Bar Examiners (NCBE) and ABA Section of Legal Education and Admissions to the Bar. 2013. Comprehensive Guide to Bar Admission Requirements 2013, ed. Erica Moeser and Claire Huisman. Madison, WI: NCBE.

Nelson, Robert L., and David M. Trubek. 1992. Arenas of Professionalism: The Professional Ideologies of Lawyers in Context. In Lawyers' Ideals/Lawyers' Practices: Transformations in the American Legal Profession, ed. Robert L. Nelson, David M. Trubek, and Rayman L. Solomon, 177-214. Ithaca, NY: Cornell University Press,

Parker, Christine, Talia Ruth Gordon, and Steve A. Mark. 2010. Regulating Law Firm Ethics Management: An Empirical Assessment of an Innovation in Regulation of the Legal Profession in New South Wales. Journal of Law \& Society 37:466-500.

Powell, Michael J. 1988. From Patrician to Professional Elite: The Transformation of the New York City Bar Association. New York: Russell Sage Foundation.

Rhode, Deborah L. 1985. Moral Character as a Professional Credential. Yale Law Journal 94:491603.

Ross, Lee. 1977. The Intuitive Psychologist and His Shortcomings: Distortions in the Attribution Process. In Advances in Experimental Social Psychology, Vol. 10, ed. Leonard Berkowitz, 173-220. New York: Academic Press.

Schmitt, David P. 2008. Why Can't a Man be More Like a Woman? Sex Differences in Big Five Personality Traits Across 55 Cultures. Joumal of Personality $\mathcal{E}$ Social Psychology 94:168-82.

Simon, Mitchell M. 2010. What's Remorse Got to Do, Got to Do with It? Bar Admission for Those with Youthful Offenses. Michigan State Law Review 2010:1001-31.

Simon, Rita J., and Heather Ahn-Redding. 2005. The Crimes Women Commit: The Punishments They Receive. Lanham, MD: Lexington Books.

Suchman, Mark C. 1998. Working Without a Net: The Sociology of Legal Ethics in Corporate Litigation. Fordham Law Review 67:837-74.

Supreme Court of Ohio and the Ohio Judicial System. 2012. Character and Fitness Determinations. http://www.supremecourt.ohio.gov/AttySvcs/admissions/cfstats/default.asp (accessed June 24, 2013).

Swisher, Keith. 2008. The Troubling Rise of the Legal Profession's Good Moral Character. St. John's Law Review 82:1037-84.

Temple, Hollee Schwartz. 2012. Speaking Up: Helping Law Students Break Through the Silence of Depression. ABA Journal, February 1, 23.

U.S. News \& World Report. 1993. America's Best Graduate Schools: Law. U.S. News $\mathcal{E}$ World Report, March 22, 51-79.

Wilkins, David B. 1992. Who Should Regulate Lawyers? Harvard Law Review 105:801-87. 
Woolley, Alice. 2007. Tending the Bar: The "Good Character" Requirement for Law Society Admission. Dalhousie Law Joumal 30:27-77.

Woolley, Alice, and Jocelyn Stacey. 2010. The Psychology of Good Character: The Past, Present and Future of Good Character Regulation in Canada. In Reaffirming Legal Ethics: Taking Stock and New Ideas, ed. Kieran Tranter et al., 165-87. London: Routledge.

Zacharias, Fred C. 2001. The Professional Discipline of Prosecutors. North Carolina Law Review 79:721-78.

Zemans, Frances Kahn, and Victor G. Rosenblum. 1981. The Making of a Public Profession. Chicago: American Bar Foundation.

\section{CASES CITED}

Konigsberg v. State Bar of Califormia, 366 U.S. 36 (1961).

Schware ข. Board of Bar Examiners, 353 U.S. 252 (1957). 


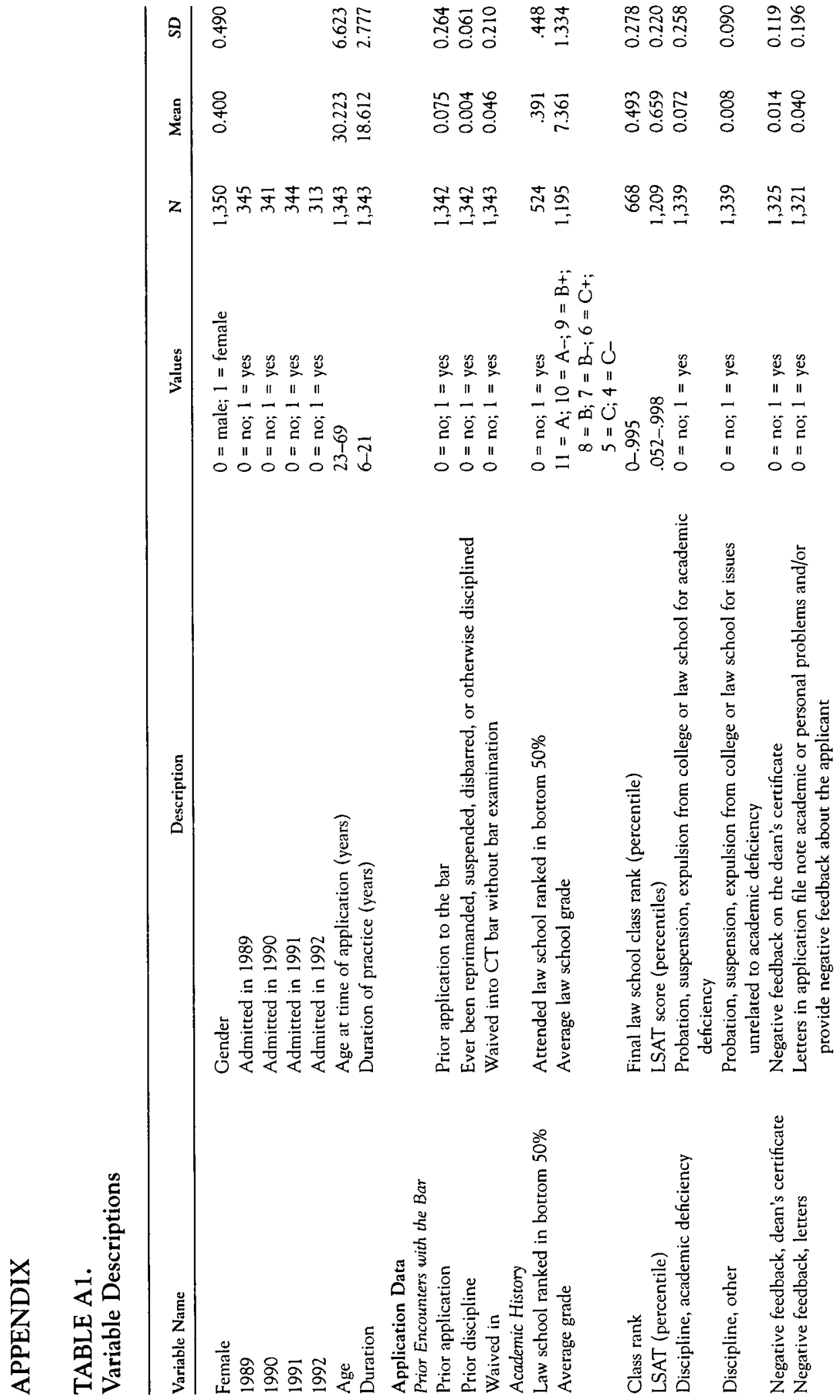




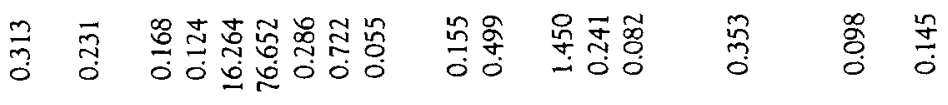

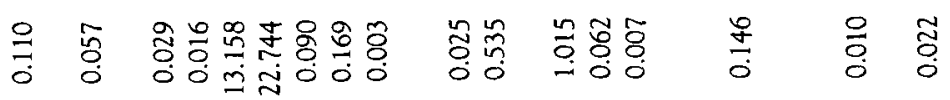

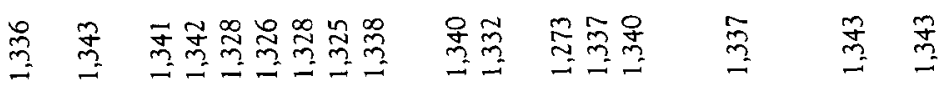

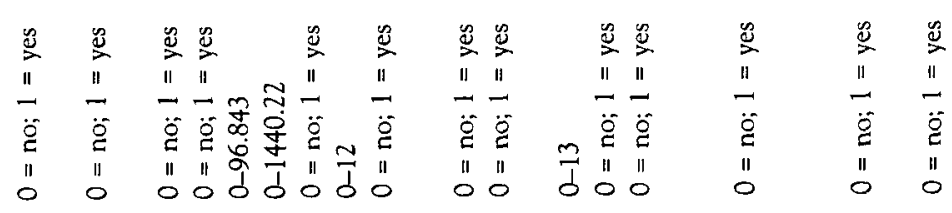
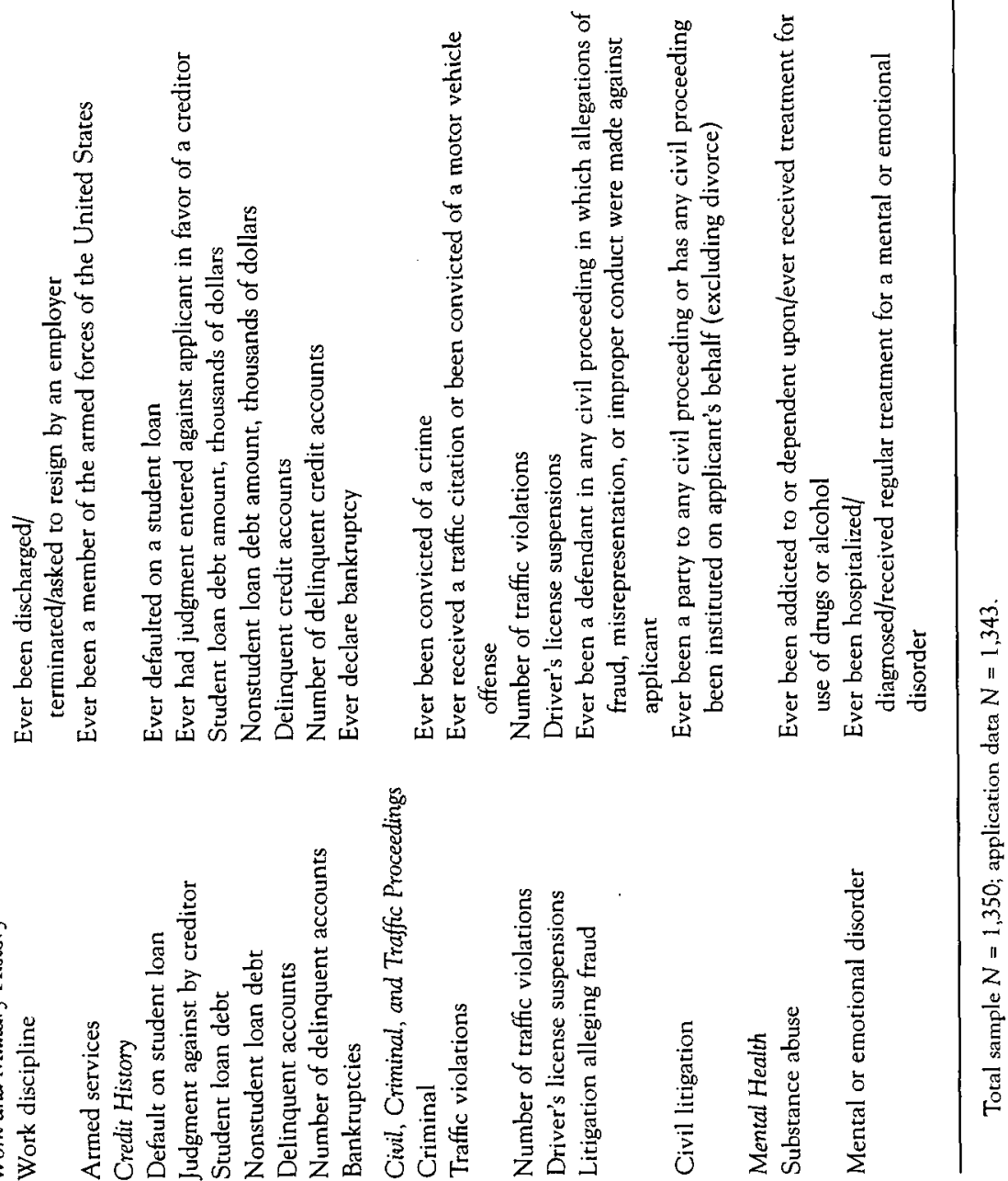